\title{
28. INORGANIC GEOCHEMISTRY OF SEDIMENTS AND ROCKS FROM THE MID-PACIFIC MOUNTAINS AND HESS RISE, DEEP SEA DRILLING PROJECT LEG 62 ${ }^{1}$
}

\author{
Walter E. Dean, U.S. Geological Survey, Denver, Colorado
}

\section{INTRODUCTION}

A total of 191 samples was collected for inorganic geochemical analyses from DSDP Holes 463, 464, 465, $465 \mathrm{~A}$, and 466 . These samples were collected with two main goals. First, at least one sample was collected from each core, whenever possible, to document the general geochemical variability within lithologic units. Unfortunately, several lithologic units were inadequately sampled because of poor recovery, mostly due to the presence of chert. The least-sampled units are Units III in Hole 464 and Units IB and II in Hole 466. The second goal was to look for geochemical differences between contrasting lithologies within main lithologic units, particularly between cyclic interbeds of red and green limestone in Lithologic Unit II, Hole 463, and between olive, laminated limestone and gray, massive limestone in Lithologic Unit II, Hole 465A.

\section{METHODS}

The 191 geochemical samples were analyzed for 30 major, minor, and trace elements using semiquantitative optical emission spectroscopy, X-ray fluorescence, and atomic-absorption spectrophotometry. Two elements ( $\mathrm{Be}$ and $\mathrm{Pb}$ ) were detected only in samples from Hole 464. Details of the analytical methods are described in the analytical sections of the report by Miesch (1976). Twenty-four of the 191 samples were chosen at random for duplicate analyses; all 215 analytical samples (191 samples plus 24 duplicates) were submitted in a random sequence to the analytical laboratories of the U.S. Geological Survey.

Samples were air-dried and ground in a ceramic mill to pass a 100 -mesh $(149 \mu \mathrm{m})$ sieve. Because the samples were air-dried, concentrations of $\mathrm{Na}$ and $\mathrm{Mg}$ are too high, owing to $\mathrm{Na}^{+}$and $\mathrm{Mg}^{+2}$ dissolved in interstitial water and left as a residue after evaporation. To correct these values, I assumed that all the $\mathrm{Cl}$ determined by X-ray fluorescence was due to $\mathrm{Cl}^{-}$dissolved in the interstitial water, and that this water contained the same proportions of $\mathrm{Na}^{+}, \mathrm{Mg}^{+2}$, and $\mathrm{Cl}^{-}$as average sea water. Contributions of $\mathrm{Mg}$ and $\mathrm{Na}$ from interstitial water were then subtracted from the analytical values.

\section{RESULTS}

\section{Site $\mathbf{4 6 3}$}

Results of analyses of 106 samples (including nine analytical duplicates) from Hole 463 are given in Table 1 and plotted versus sub-bottom depth in Figure 1.

Lithologic Unit I consists of foraminifer and nannofossil ooze and chalk. Concentrations of $\mathrm{CaCO}_{3}$ range from about 70 to $100 \%$, but concentrations in most samples are greater than $90 \%$ (Site 463 report, this

\footnotetext{
${ }^{1}$ Initial Reports of the Deep Sea Drilling Project, Volume 62.
}

volume). Silicification of chalk associated with chert occurs below Core 30 , and this is indicated by higher $\mathrm{Si}$ concentrations in some samples (Fig. 1). The most notable chemical characteristics of the ooze and chalk in Unit I are the relatively high concentrations of $\mathrm{Ba}$ (average of about $1200 \mathrm{ppm}$ ) and Sr (range of about 1000 to $3000 \mathrm{ppm}$ ). Concentrations of $\mathrm{Sr}$ decrease steadily with depth, from about $3000 \mathrm{ppm}(0.3 \%)$ or more near the sediment/water interface to about 500 ppm in limestones in Units II, III, and IV. I interpret this decrease with depth to represent progressive loss of $\mathrm{Sr}$ during diagenesis. Wangersky and Joensuu (1964, 1967) reported average values of $\mathrm{Sr}$ ranging from 1500 to $1700 \mathrm{ppm}$ in coarse fractions $(>62 \mu \mathrm{m})$ of samples from five deep-sea carbonate cores from the Atlantic and Caribbean. Average values of $\mathrm{Sr}$ in the fine fractions from the same 5 cores ranged from 1900 to 2300 ppm. Turekian (1964) reported an average concentration of $1200 \mathrm{ppm} \mathrm{Sr}$ in foraminifer $\mathrm{CaCO}_{3}$. Samples from Hole 463, therefore, appear to be higher in $\mathrm{Sr}$ than expected in ooze (Unit IA), and lower than expected in limestone.

Unit II consists of cyclic interbeds of greenish-gray limestone with gray, white, or red limestone. All the limestones show varying degrees of silicification, indicated by variations in the concentration of $\mathrm{Si}$ (Fig. 1). The most pronounced color difference is between the greenish-gray and reddish- or pinkish-gray limestones in Cores 57 through 65 (Fig. 2). Chemical differences between green and red limestones will be discussed later.

Unit III consists of limestone similar to the multicolored limestones in Unit II, with the addition of beds of tuff-rich limestone and (in Cores 70 and 71), organiccarbon-rich limestone that contains up to $4 \%$ organic carbon (Dean et al., this volume). A considerable amount of silicification occurs in all the limestones in Unit III, especially in the organic-carbon-rich limestones (Fig. 1). Most elements show a greater range of variability between samples of limestone from both Units II and III relative to element variability within overlying and underlying units. This is particularly evident for $\mathrm{Si}, \mathrm{Al}, \mathrm{K}, \mathrm{Ti}, \mathrm{B}, \mathrm{Ba}, \mathrm{Cr}, \mathrm{Cu}, \mathrm{Mn}, \mathrm{Zn}$, and $\mathrm{Zr}$.

Summary statistics for analyses of 18 samples of red limestone and 16 samples of green limestone from Unit II (Cores 57-64, 500 to $560 \mathrm{~m}$ sub-bottom) are given in Table 2 and plotted in Figure 3. These samples are indicated in Table 1 by " $g$ " (green) and " $r$ " (red) following the interval designation for samples. It is apparent from Table 2 and Figure 3 that the red limestones contain higher concentrations of most elements than the 
Table 1. Chemical analyses of samples from Hole 463.

\begin{tabular}{|c|c|c|}
\hline Sample & $\begin{array}{l}\text { Site-Core-Section, } \\
\text { Interval (cm) }\end{array}$ & $\begin{array}{l}\text { Sub-bottom } \\
\text { Depth } \\
\text { (m) }\end{array}$ \\
\hline 30012041 & $463 \cdot-2,41$ & 1.91 \\
\hline 30022050 & $463-2-2,30$ & 7.50 \\
\hline 30032036 & $463 \cdot 3 \cdot 2,36$ & 16.86 \\
\hline $\begin{array}{l}3004036 \\
3004037\end{array}$ & $\begin{array}{l}463.44,436 \\
463.43\end{array}$ & 29.36 \\
\hline $\begin{array}{l}300404037 \\
30052028\end{array}$ & $\begin{array}{l}463-4-4,36 \\
463-5,2,28\end{array}$ & $\begin{array}{l}29.36 \\
35.78\end{array}$ \\
\hline 30062038 & $403-6 \cdot 2,38$ & $\begin{array}{l}39.88 \\
39.88\end{array}$ \\
\hline 30072050 & $463.7-2,50$ & 45.50 \\
\hline 30083022 & $463 \cdot 8 \cdot 3,22$ & 56.22 \\
\hline $\begin{array}{l}30092070 \\
30100050\end{array}$ & $463 \cdot 9 \cdot 2,70$ & 64.70 \\
\hline $\begin{array}{l}301000050 \\
30112073\end{array}$ & $463-10-4,50$ & $\begin{array}{l}77.00 \\
83.73\end{array}$ \\
\hline $\begin{array}{l}3011202025 \\
301025\end{array}$ & $\begin{array}{l}463-11-2,73 \\
463-12-1,25\end{array}$ & $\begin{array}{l}83.73 \\
91.25\end{array}$ \\
\hline $\begin{array}{l}30132067 \\
301320\end{array}$ & $\begin{array}{l}463-12-1,25 \\
463-13-2,67\end{array}$ & $\begin{array}{r}91,23 \\
102.67\end{array}$ \\
\hline $\begin{array}{l}30144052 \\
301320\end{array}$ & $\begin{array}{l}40301-13-2,67 \\
463-14-4,52\end{array}$ & $\begin{array}{l}\begin{array}{l}102.67 \\
115.02\end{array} \\
11\end{array}$ \\
\hline 30152036 & $463-15-2,56$ & 121.56 \\
\hline 30162058 & $463-16-2,58$ & 131.08 \\
\hline $\begin{array}{l}30172098 \\
30192060\end{array}$ & $\begin{array}{l}463-17-2,98 \\
436-26\end{array}$ & 140.98 \\
\hline $\begin{array}{l}\begin{array}{l}301920600 \\
30201102\end{array} \\
0.04\end{array}$ & $\begin{array}{l}443-19-2,60 \\
463-20-1,102\end{array}$ & $\begin{array}{l}159.60 \\
168.02\end{array}$ \\
\hline 30212103 & $463 \cdot 21 \cdot 2,103$ & 179.03 \\
\hline & $463-22-2,54$ & 188.04 \\
\hline 30231030 & $463-23-1,30$ & 195.80 \\
\hline 30242119 & $463-24-2,119$ & 202.19 \\
\hline 30252053 & $463 \cdot 25 \cdot 2,53$ & 207.03 \\
\hline 30262059 & $463-26-2,59$ & 216.09 \\
\hline 30262060 & $463-26-2,59$ & 216.09 \\
\hline $\begin{array}{l}30264128 \\
30272008\end{array}$ & $\begin{array}{l}463-26-4,128 \\
463.27-2,8\end{array}$ & $\begin{array}{l}220.27 \\
225.48\end{array}$ \\
\hline $\begin{array}{l}3027202008 \\
30291012\end{array}$ & $\begin{array}{l}463-27-2,8 \\
463-29.1,12\end{array}$ & $\begin{array}{l}225.58 \\
243.12\end{array}$ \\
\hline $30301030^{\circ}$ & $463-30-1,30$ & 252.80 \\
\hline 30311003 & $463-31-1,3$ & 262.03 \\
\hline 30331104 & $463-33-1,104$ & 282.04 \\
\hline 30342070 & & 292.70 \\
\hline 30351014 & $463-35-1,14$ & 300.14 \\
\hline $\begin{array}{l}30361013 \\
3038106\end{array}$ & $463-36-1,13$ & 309.63 \\
\hline $\begin{array}{l}303841062 \\
30432034\end{array}$ & $\begin{array}{l}463-38-1,62 \\
463-43 \cdot 2,34\end{array}$ & $\begin{array}{l}329,12 \\
377.84\end{array}$ \\
\hline $\begin{array}{l}3048202027 \\
304827\end{array}$ & $\begin{array}{l}463-433.2,34 \\
463-48 \cdot 2,27\end{array}$ & $\begin{array}{l}377.84 \\
425.27\end{array}$ \\
\hline 30482028 & $463-48 \cdot 2,27$ & 425.27 \\
\hline 30501039 & $463-50-1,39$ & 433.39 \\
\hline 30538026 & $463-53-8,26$ & 463.16 \\
\hline 30551004 & $463-55-1,4$ & 480.54 \\
\hline 30561022 & $\begin{array}{l}463-56-1,22 \\
463.57,\end{array}$ & 490.22 \\
\hline $\begin{array}{l}30571018 \\
3057018\end{array}$ & $\begin{array}{l}463.57 \cdot 1,188 \\
463.57 .199\end{array}$ & 499.68 \\
\hline $\begin{array}{l}305781019 \\
03058010\end{array}$ & $\begin{array}{l}463-53-1.19 \mathrm{r} \\
463 \cdot 58-1,10 \mathrm{~g}\end{array}$ & 499.69 \\
\hline $\begin{array}{l}30581014 \\
305810\end{array}$ & $\begin{array}{l}463-58-1,1,108 \\
463 \cdot 58-1,145\end{array}$ & $\begin{array}{l}509.10 \\
509.14\end{array}$ \\
\hline 30581015 & $463-58-1,14 r$ & $\begin{aligned} 509.14 \\
5094\end{aligned}$ \\
\hline 30583014 & $463-58-3,14 \mathrm{~g}$ & 512.14 \\
\hline 30583020 & $463-58-3,20 \mathrm{r}$ & 512.20 \\
\hline 30583066 & 463-58-3, 66r & 512.66 \\
\hline 30583071 & $463-58-3,71 \mathrm{~g}$ & 512.71 \\
\hline 30591001 & $463-59-1,18$ & 518.51 \\
\hline 30591007 & $463-59-1,78$ & 518.57 \\
\hline $\begin{array}{l}305991106 \\
03059114\end{array}$ & $\begin{array}{l}463.59-1.1068 \\
463-59-1,114 \mathrm{r}\end{array}$ & $\begin{array}{l}519.56 \\
519.64\end{array}$ \\
\hline 30593106 & $\begin{array}{l}4663-99-1,1114 \\
463-59-3,106 \mathrm{r}\end{array}$ & $\begin{array}{l}5192.64 \\
522.56\end{array}$ \\
\hline 30593120 & $463-59-3,120 r$ & 522.70 \\
\hline 30602010 & $463-60-2,108$ & 529.60 \\
\hline 30602013 & $463-60-2,13 \mathrm{r}$ & 529.63 \\
\hline 30603000 & $463-60-3,1 \mathrm{~g}$ & 531.00 \\
\hline 30603005 & $463-60-3,5 \mathrm{~s}$ & 531.05 \\
\hline 30611 & $463-61-1,28 \mathrm{r}$ & \\
\hline $\begin{array}{l}30611029 \\
03627201\end{array}$ & $463-61-1,28 r$ & 535.78 \\
\hline $\begin{array}{l}30622202017 \\
30622018\end{array}$ & $\begin{array}{l}463-62-2,178 \\
463-62-2,178\end{array}$ & $\begin{array}{l}539.17 \\
539.17\end{array}$ \\
\hline $\begin{array}{l}306222018 \\
0.0622035\end{array}$ & $\begin{array}{l}463-62-2,178 \\
463-62-2,35 \mathrm{r}\end{array}$ & $\begin{array}{l}539.17 \\
539.35\end{array}$ \\
\hline 30623078 & $463-62-3,78 g$ & $\begin{array}{l}541.28 \\
39.39\end{array}$ \\
\hline 30623084 & $463-62-3,84 r$ & 541.34 \\
\hline 30632002 & $463-63-2,2 x$ & $\$ 48.52$ \\
\hline 30632005 & $463-63-2,5_{8}$ & 548.55 \\
\hline 30638 & $463-63$ & \\
\hline 30638016 & $463-63-8,16 \mathrm{~g}$ & 550.61 \\
\hline $\begin{array}{l}30642091 \\
3064200 \%\end{array}$ & 463-64-2, 91r & $\begin{array}{l}558.91 \\
\$ \$ 8.96\end{array}$ \\
\hline $\begin{array}{l}3064202096 \\
3064131\end{array}$ & $\begin{array}{l}466-64-2,968 \\
463-64-2,1318\end{array}$ & $\begin{array}{l}558.96 \\
559.31\end{array}$ \\
\hline $\begin{array}{l}3064211311 \\
30642137\end{array}$ & $\begin{array}{l}463-64-2,1318 \\
463-64-2,137 t\end{array}$ & $\begin{array}{l}559.31 \\
559.37\end{array}$ \\
\hline 30672056 & $463-67-2,56$ & 587.06 \\
\hline 30691030 & $463-69-1,30$ & 604.30 \\
\hline 30691 & $463-69-1,40$ & 60 \\
\hline 30701069 & 46 & \\
\hline 30703035 & & \\
\hline $\begin{array}{l}30703036 \\
30706044\end{array}$ & $\begin{array}{l}463-70-3,35 \\
\text {, } 352-756\end{array}$ & 616.85 \\
\hline $\begin{array}{l}3070600041 \\
3072\end{array}$ & $\begin{array}{r}463-70-6,41 \\
436-70-61\end{array}$ & $\begin{array}{l}621.41 \\
621.41\end{array}$ \\
\hline 30700042 & $\begin{array}{l}463-70-6,41 \\
463-71-10\end{array}$ & $\begin{array}{l}621.41 \\
624,10\end{array}$ \\
\hline 30711 & $\begin{array}{l}403-71-1,1 \\
463-71-1,1\end{array}$ & 624.21 \\
\hline & $463-71-1,134$ & \\
\hline 30722 & $463-72 \cdot 2,38$ & \\
\hline 30723064 & 46 & \\
\hline 30724062 & $463-72$ & \\
\hline 30731036 & $463-73-1,36$ & 642.36 \\
\hline 20731059 & $\begin{array}{l}463-73-1,49 \\
463-73-1,59\end{array}$ & $\begin{array}{l}642.49 \\
642.59\end{array}$ \\
\hline 30741028 & $\begin{array}{l}463-73-1,59 \\
463-74,28\end{array}$ & $\begin{array}{l}642.59 \\
651.79\end{array}$ \\
\hline 30751052 & 463.75 & 66 \\
\hline & & \\
\hline & & \\
\hline & & \\
\hline & & \\
\hline & & \\
\hline & & \\
\hline & & 729. \\
\hline 30851075 & 463-8: & \\
\hline 30851076 & $463-85-1,75$ & 747.25 \\
\hline
\end{tabular}

Note: Analyses were by X-ray fluorescence (xrf), semiquantitative optical emission spectroscopy (S), or atomic absorption (aa); analytical values for $\mathrm{Mz}$ and $\mathrm{Na}$ by atomic absorption were corrected for interstitial sea water (swc; see text for method of correction). Letter designations following intervals are: 8 , sample of greenish-gray limestone from Lithologic Unit $11 ; \mathrm{r}$, sample of reddish- or pinkish-gray limestone from Lithologic Unit 11 . 


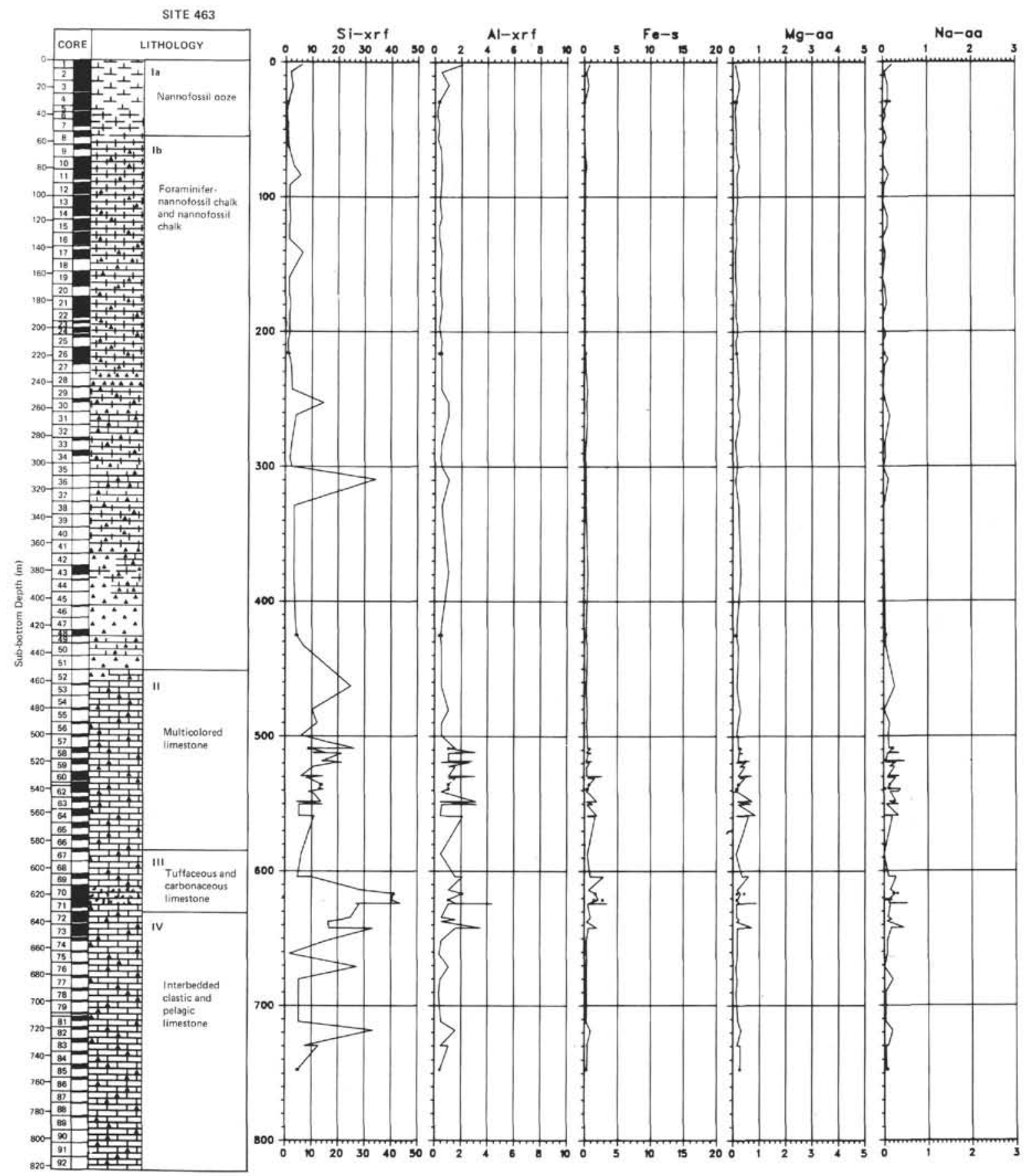

Figure 1. Lithologic summary and plots of element concentrations in samples from Hole 463. Element concentrations are in percent (unlabeled) or parts per million (labeled ppm) dry weight. Analyses were by X-ray fluorescence (xrf), semiquantitative optical emission spectroscopy (s), or atomic absorption spectrophotometry (aa). Duplicate analyses are indicated by two points connected by a horizontal bar at the same depth. The thickness of the black interval beside each core number in the column labeled "core" indicates the proportion of the cored interval that was recovered.

green limestones. These differences appear to be greatest in limestone samples from Cores 60 through 64 (Table 1), and for $\mathrm{Fe}, \mathrm{Mg}, \mathrm{Na}, \mathrm{Ti}, \mathrm{Co}, \mathrm{Cr}, \mathrm{Cu}, \mathrm{Ni}$, and $\mathrm{V}$. There are no differences in concentrations of $\mathrm{Si}$ and $\mathrm{Al}$ between red and green limestones that would indicate that one or the other contained more clay minerals. Therefore, I interpret the higher element concentrations in the red limestones to be the result of greater adsorp- tion by hydrous ferric oxides which I assume give the red limestones their distinctive color.

\section{Site 464}

Results of analyses of 15 samples (including four analytical duplicates) from Hole 464 are given in Table 3 and plotted versus sub-bottom depth in Figure 4. Twelve of these 15 samples are from brown clay, and 

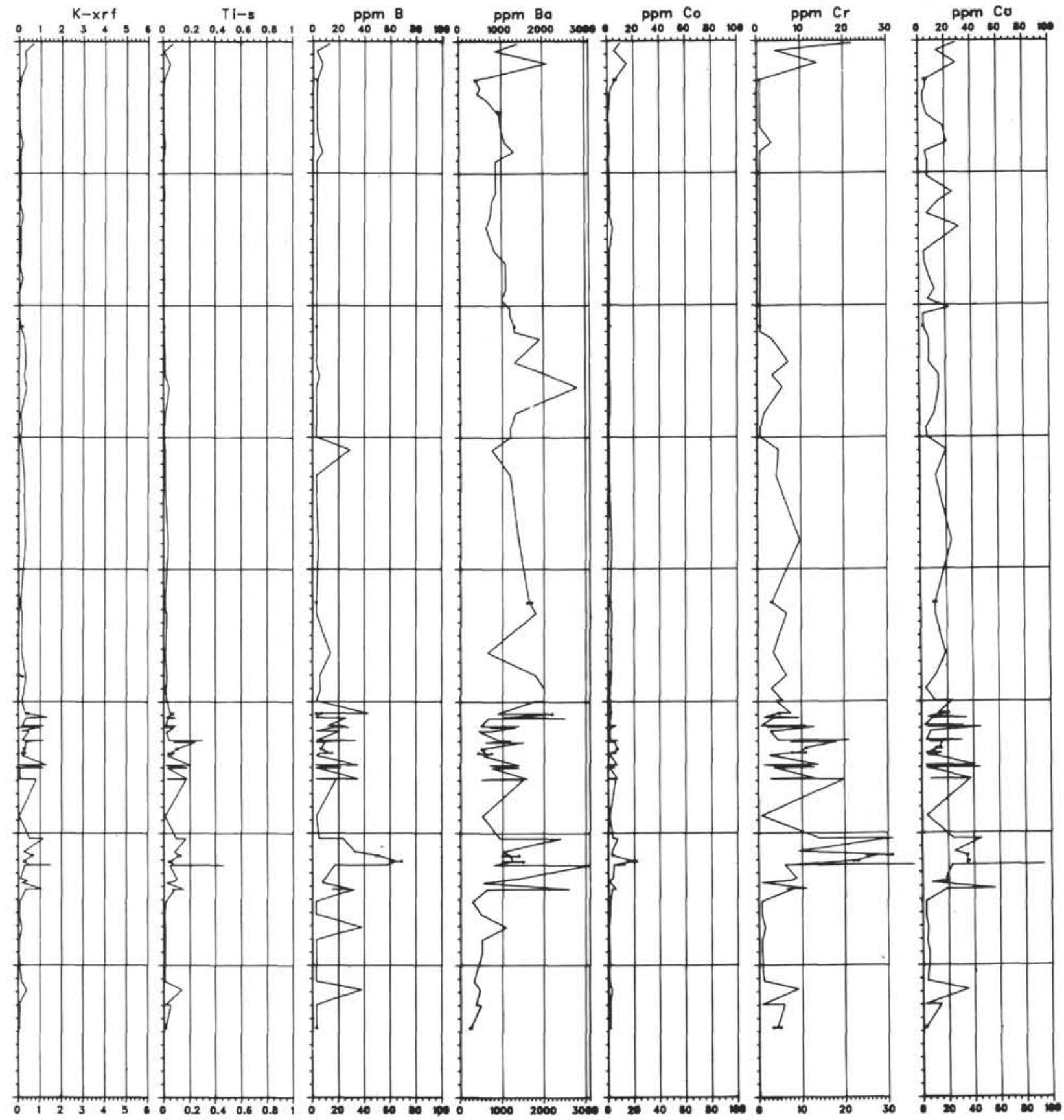

Figure 1. (Continued).

summary statistics for these samples are given in Table 4. Because Site 464 is below the carbonate-compensation depth, and apparently has been at least since the Miocene, there is no carbonate dilution of pelagic clays. This brown pelagic clay contains especially high concentrations of $\mathrm{Fe}$ and $\mathrm{Mn}$ due to hydrated oxides of $\mathrm{Fe}$ and $\mathrm{Mn}$, which are known to be effective scavengers of trace metals, particularly $\mathrm{Ni}, \mathrm{Cu}, \mathrm{Co}, \mathrm{Zn}$ - and to a lesser extent $\mathrm{Cr}, \mathrm{Mo}, \mathrm{Ba}$, and $\mathrm{Pb}$ (e.g., Burns and Brown, 1972; Varentsov and Pronina, 1973; Burns and Burns, 1977).
The combination of no carbonate dilution and tracemetal scavenging results in higher concentrations of most elements relative to carbonate samples from the other three sites.

\section{Site $\mathbf{4 6 5}$}

Results of analyses of 62 samples (including six analytical duplicates) from Holes 465 and $465 \mathrm{~A}$ are given in Table 5 and plotted versus sub-bottom depth in Figure 5. Unit I consists of white nannofossil ooze or 

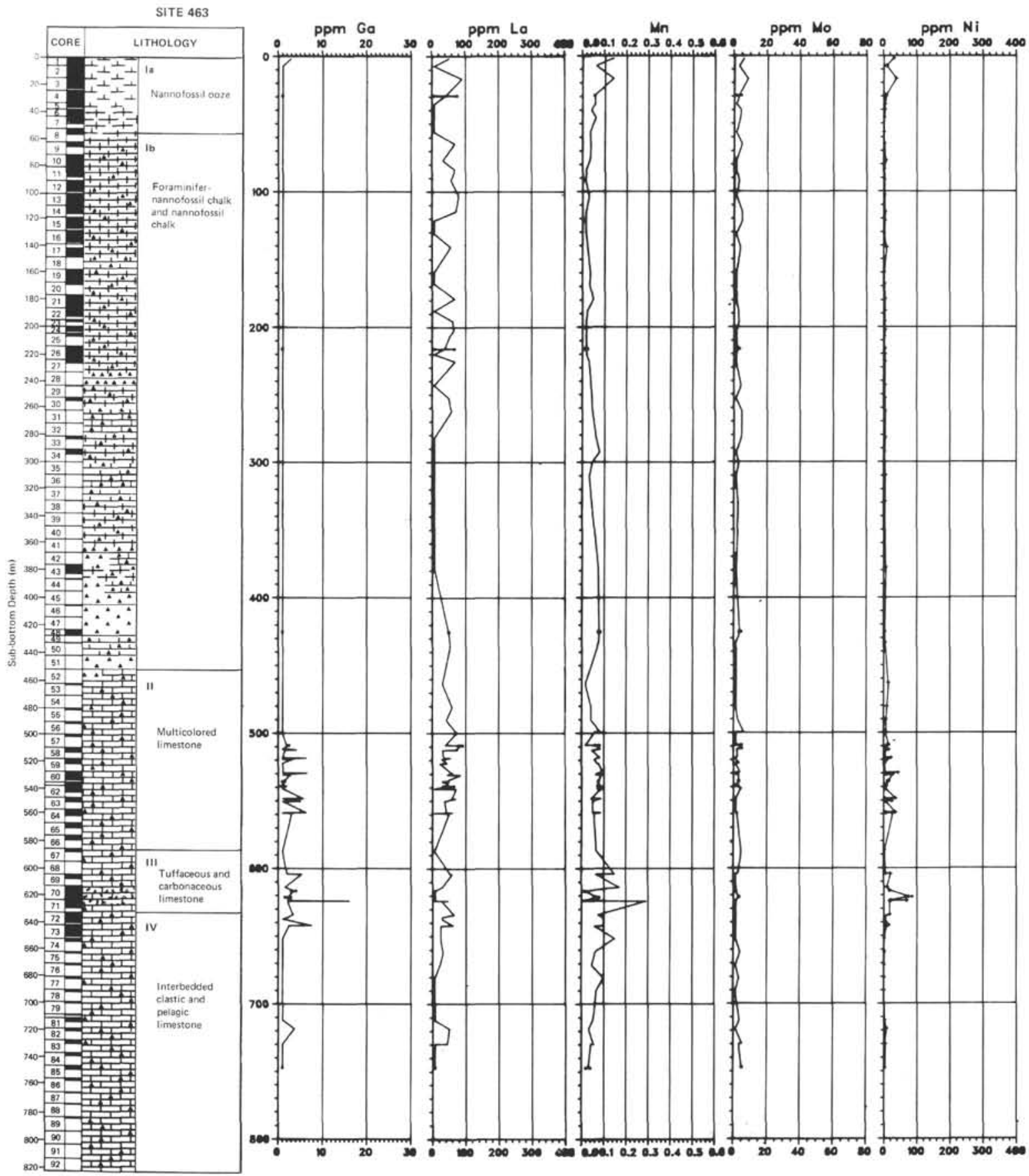

Figure 1. (Continued).

foraminifer-nannofossil ooze. Concentrations of $\mathrm{CaCO}_{3}$ range from 81 to $96 \%$, but concentrations in most samples are greater than $90 \%$ (Site 465 report, this volume). Blebs of pyrite in Core 3A (62 meters sub-bottom) smeared into the ooze by the coring process have imparted an overall gray color to the ooze. These pyrite concentrations are associated with higher concentrations of a number of elements in samples from this depth. There are actually three samples collected between 61.88 and 62.64 meters sub-bottom that represent a transition from ooze to ooze with high concentrations of pyrite. The geochemical gradient represented by these three samples is evident in Figure 5 and Table 5.

The concentrations of $\mathrm{Sr}$ decrease from about 3000 $\mathrm{ppm}(0.03 \%)$ at the sediment/water interface, to about $2000 \mathrm{ppm}$ in samples of ooze, to an average of about $1000 \mathrm{ppm}$ in samples of limestone from Unit II. This decrease in $\mathrm{Sr}$ with depth is more gradual and not as pronounced as in Hole 463 (Fig. 1). Concentrations of $\mathrm{Ba}$ in ooze from Hole 465 and $465 \mathrm{~A}$ are also high (average of about $740 \mathrm{ppm}$ ), but not as high as in ooze and chalk from Hole 463 (average of about $1200 \mathrm{ppm}$ ). 


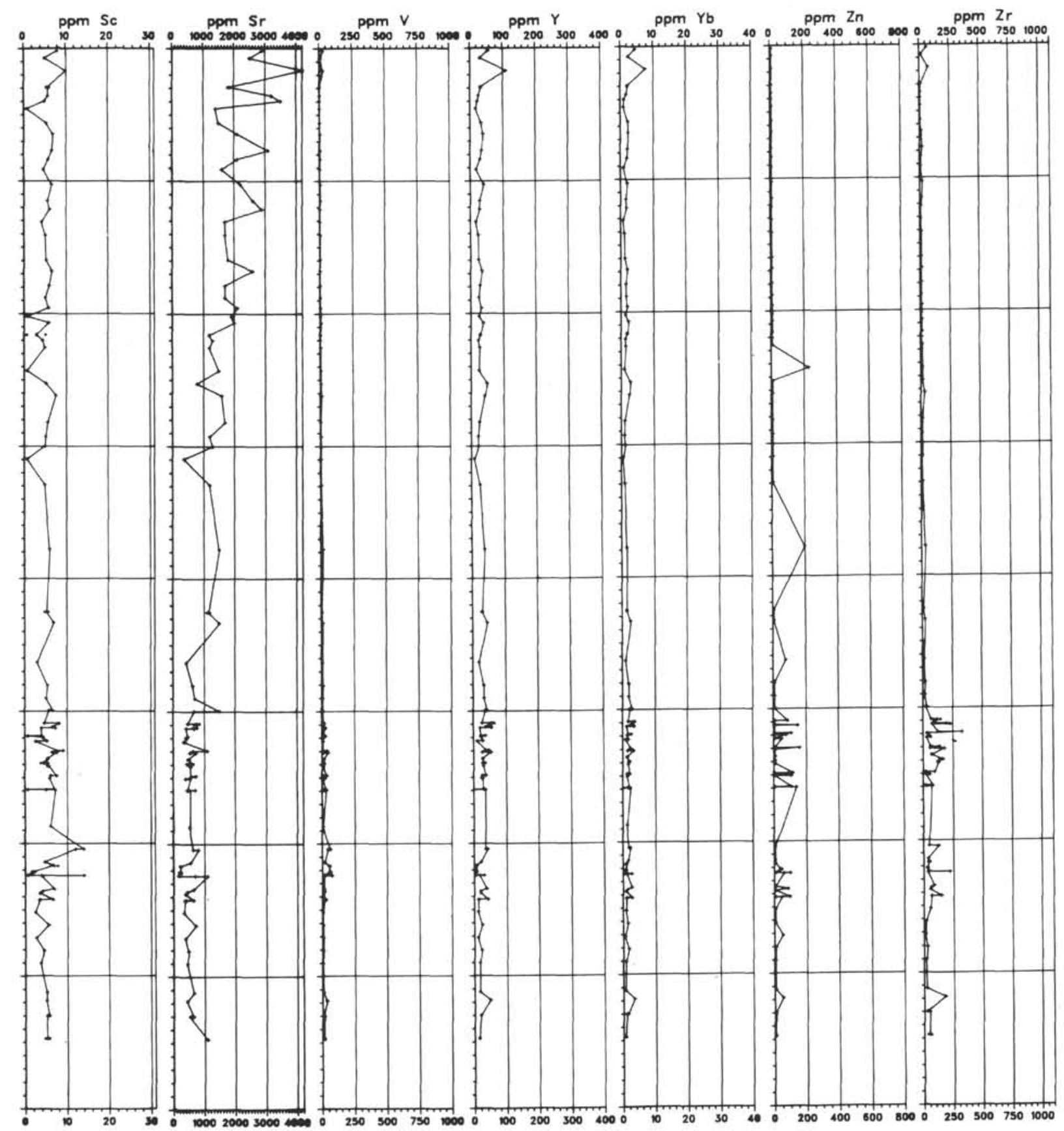

Figure 1. (Continued).

The dominant lithology of Unit II in Hole 465A is olive-gray laminated limestone (Fig. 6) that contains up to $8.6 \%$ organic carbon (Dean et al., this volume).

Most samples of olive limestone contain between 80 and $90 \% \mathrm{CaCO}_{3}$. This unit also contains rare to common interbeds of gray, massive to faintly laminated limestone (Fig. 6) that make up about $5 \%$ of the total thickness of Unit II (Site 465 report, this volume).

Summary statistics for analyses of 5 samples of gray massive limestone and 24 samples of olive laminated limestone from Unit II are given in Table 6 and plotted in Figure 7. Samples of gray limestone are indicated by arrows on the plot for $\mathrm{Si}$ in Figure 5, and by a "g" following the interval designation for samples in Table 5 ; olive-gray limestone samples are indicated by "ol" following the interval designation in Table 5 . The variability in concentrations of $\mathrm{Si}$, evident in Figure 5, is due mainly to the higher degree of silicification of gray limestone relative to olive limestone (Table 6; Figure 7), although even the gray limestones are considerably less silicified than limestones in Units II and III in Hole 463 (Fig. 1). 


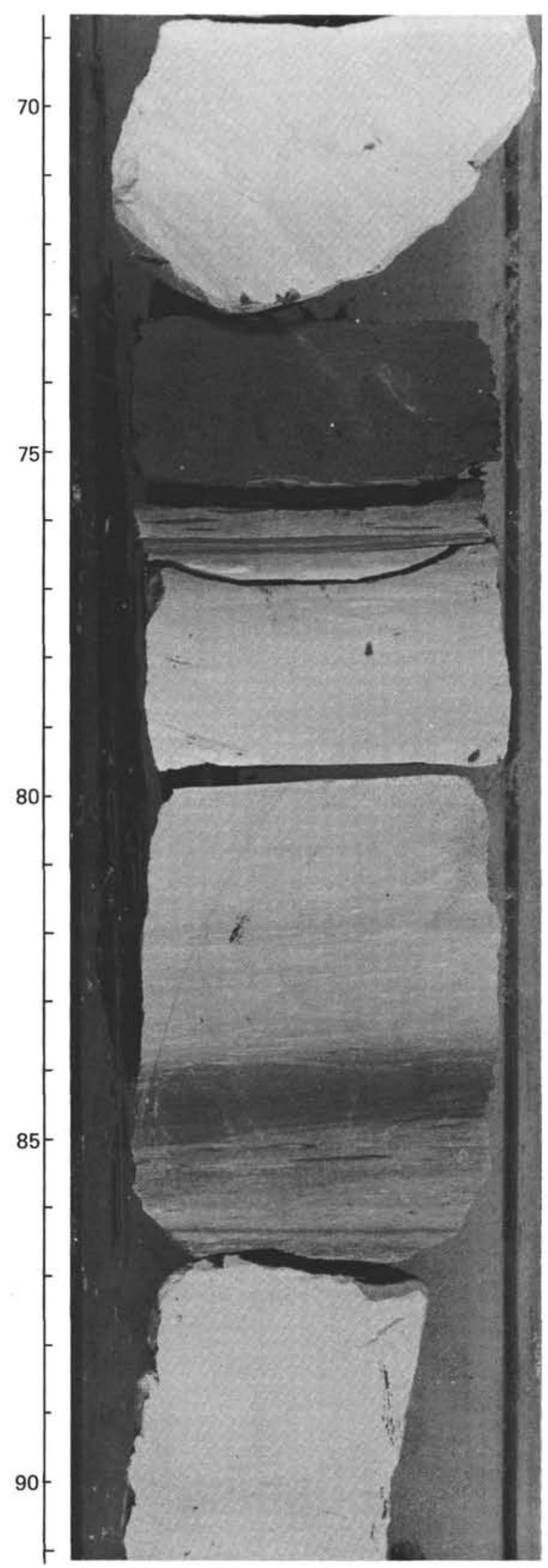

Figure 2. Interbeds of pinkish- or reddish-gray (dark) and greenishgray (light) limestone from Lithologic Unit II, 463-67-2, 70-90 cm. Subdivisions on scale are in millimeters.
Table 2. Summary statistics for element concentrations in 18 samples of red limestone and 16 samples of green limestone from Lithologic Unit II, Hole 463.

\begin{tabular}{|c|c|c|c|c|c|c|}
\hline \multirow[b]{2}{*}{ Element } & \multicolumn{3}{|c|}{ Red Limestone } & \multicolumn{3}{|c|}{ Green Limestone } \\
\hline & $\begin{array}{c}\text { Observed } \\
\text { Range }\end{array}$ & $\begin{array}{l}\text { Arithmetic } \\
\text { Mean }\end{array}$ & $\begin{array}{l}\text { Standard } \\
\text { Deviation }\end{array}$ & $\begin{array}{c}\text { Observed } \\
\text { Range }\end{array}$ & $\begin{array}{l}\text { Arithmetic } \\
\text { Mean }\end{array}$ & $\begin{array}{l}\text { Standard } \\
\text { Deviation }\end{array}$ \\
\hline Si $(\%)$ & $5.1-19$ & 12 & 3.3 & $4.3-26$ & 12 & 6.6 \\
\hline $\mathrm{Al}$ & $<0.42-3.2$ & 1.6 & 0.91 & $<0.42-3.1$ & 1.1 & 0.80 \\
\hline $\mathrm{Fe}$ & $0.41-2.7$ & 1.1 & 0.62 & $0.34-1.2$ & 0.53 & 0.20 \\
\hline $\mathrm{Mg}$ & $0.19-0.84$ & 0.42 & 0.21 & $0.075-0.65$ & 0.22 & 0.13 \\
\hline $\mathrm{Na}$ & $0.11-0.38$ & 0.24 & 0.085 & $0.024-0.48$ & 0.12 & 0.12 \\
\hline $\mathrm{K}$ & $0.08-1.3$ & 0.56 & 0.39 & $<0.017-1.3$ & 0.33 & 0.38 \\
\hline $\mathrm{Ti}$ & $<0.013-0.22$ & 0.079 & 0.063 & $<0.013-0.18$ & 0.040 & 0.023 \\
\hline $\mathrm{Ba}(\mathrm{ppm})$ & $430-2500$ & 1300 & 650 & $420-2000$ & 820 & 390 \\
\hline Co & $1.2-7.5$ & 3.9 & 2.5 & $0.70-6.1$ & 2.2 & 1.6 \\
\hline $\mathrm{Cr}$ & $2.8-21$ & 10 & 5.8 & $0.70-11$ & 5.0 & 3.3 \\
\hline $\mathrm{Cu}$ & $6.7-46$ & 24 & 13 & $2.5-38$ & 9.5 & 10 \\
\hline La & 23-91 & 57 & 21 & $<7.0-73$ & 45 & 21 \\
\hline $\mathrm{Li}$ & $<7.0-13$ & 7.9 & 1.9 & $<7,0-13$ & 7.4 & 1.5 \\
\hline Mn & $410-900$ & 690 & 142 & $170-930$ & 700 & 190 \\
\hline Mo & $<1.5-4.9$ & 2.4 & 1.1 & $<1.5-6.3$ & 2.7 & 1.7 \\
\hline $\mathrm{Ni}$ & $2.2-43$ & 17 & 12 & $2.3-23$ & 7.2 & 5.4 \\
\hline $\mathrm{Sc}$ & $2.5-9.1$ & 6.3 & 1.6 & $<0.7-7.5$ & 4.8 & 1.9 \\
\hline Sr & $330-850$ & 550 & 140 & $420-1500$ & 650 & 290 \\
\hline $\mathrm{v}$ & $6.4-48$ & 22 & 12 & $6.9-29$ & 13 & 5.9 \\
\hline Y & $11-65$ & 37 & 15 & $<1.0-43$ & 28 & 10 \\
\hline $\mathrm{Yb}$ & $0.94-3.8$ & 2.3 & 0.88 & $0.10-3.0$ & 1.8 & 0.68 \\
\hline $\mathrm{Zr}$ & $29-230$ & 100 & 58 & $19-330$ & 89 & 80 \\
\hline
\end{tabular}

Relative to the olive limestones, the gray limestones also contain 10 times more $\mathrm{Ba}$, as much as five times more $\mathrm{Na}, \mathrm{Ti}$, and $\mathrm{Zr}$, and 2 to 4 times more $\mathrm{Al}, \mathrm{Fe}, \mathrm{Mg}$, $\mathrm{K}, \mathrm{La}$, and $\mathrm{Li}$. Compositions of the gray limestones also tend to be less variable than those of the olive limestones. Relative to the gray limestones, the olive limestones tend to contain higher concentrations of the transition elements, especially $\mathrm{Cu}$ (5 times higher), $\mathrm{Ni}(5$ times higher), $\mathrm{Cr}, \mathrm{Mn}, \mathrm{Mo}$, and $\mathrm{V}$. The olive limestones also contain about twice as much $\mathrm{Sr}$ as the gray limestone; this difference is probably due to less dilution of Sr-bearing carbonate by silica.

Some trace-element enrichment in the organic-carbon-rich olive limestones may be due to concentration of these elements in organic matter. The association of certain trace elements-especially $\mathrm{Cu}, \mathrm{Zn}, \mathrm{Mo}, \mathrm{V}, \mathrm{Ni}$, $\mathrm{Cr}, \mathrm{Ba}$, and $\mathrm{Pb}-$ with organic-carbon-rich sediments and rocks has been reported by many investigators (e.g., Wedepohl, 1964; Brongersma-Sanders, 1965; Calvert and Price, 1970; Vine and Tourtelot, 1970; Volkov and Fomina, 1974; Chester, et al., 1978, to name only a few).

The association of organic matter and high traceelement concentrations is usually assumed to be the result of concentrations of elements by living organisms. For example, the data of Martin and Knauer (1973) indicate that plankton are enriched in $\mathrm{Pb}, \mathrm{Ni}$, $\mathrm{Cu}, \mathrm{Mn}, \mathrm{Fe}$, and $\mathrm{Zn}$. Holland (1979) suggested, however, that high concentrations of certain trace elements in organic-carbon-rich black shales may be more related to chemical precipitation and reaction with organic detritus under anoxic conditions than to incorporation into living organisms. Unfortunately, it is not possible to separate the effects of chemical precipitation and bioconcentration, especially in anoxic, organic-carbonrich strata. Both processes may have contributed to high concentrations of some trace elements in the organiccarbon-rich limestones in Unit II, Hole 465A, and in Unit III, Hole 463. 


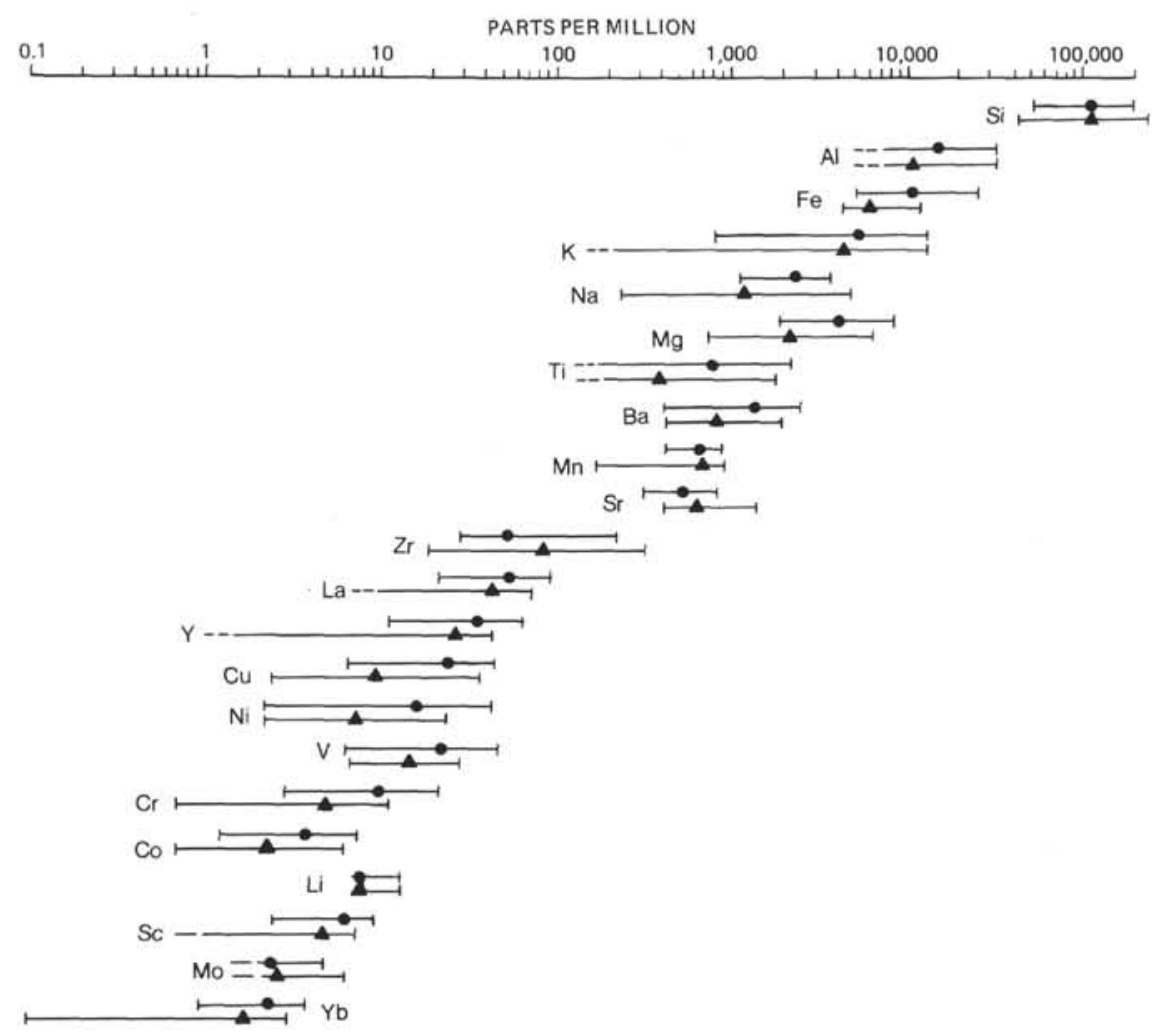

Figure 3. Comparison of element concentrations in 18 samples of red limestone (dots) and 16 samples of green limestone (triangles) from Lithologic Unit II, Hole 463. Dots and triangles represent the mean concentration for each element (Table 2). Bars indicate observed ranges of element concentrations (Table 2). A dash at the lower end of a bar indicates that the lowest concentration of the element was below the limit of detection.

Extreme variations in element concentrations in samples of olive-gray laminated limestone immediately overlying trachyte in Core 40 are evident in Figure 5 and Table 5, and are discussed by Dean et al. in their paper on geochemistry of rocks above basement at Site 465 (this volume). These samples were not included in the summary statistics for olive laminated limestone in Figure 7 and Table 6.

\section{Site 466}

Results of analyses of 33 samples (including five analytical duplicates) from Hole 466 are given in Table 7 and plotted versus sub-bottom depth in Figure 8 . Because of the abundance of chert below about 84 meters sub-bottom, the only lithologic units that could be adequately sampled in Hole 466 were Unit IA and the top of Unit IB. Both units consist mainly of white nannofossil ooze. Unit IA contains higher concentrations of impurities, as indicated by common gray and brown zones and higher concentrations of siliceous microfossils, clay, zeolites, hematite, and volcanic glass (as observed in smear slides), relative to nannofossil oozes from Unit IB and those from Sites 463 and 465 (see lithologic descriptions in site chapters, this volume).
Most samples from Unit IA contain between 70 and $90 \% \mathrm{CaCO}_{3}$, whereas all samples from Unit IB contain more than $90 \% \mathrm{CaCO}_{3}$.

Higher concentrations of impurities in Unit IA are further reflected by higher and more-variable concentrations of most elements. Summary statistics of element concentrations in nannofossil ooze and chalk from Sites 463,465 , and 466 are presented in Table 8 and plotted in Figure 9. Higher concentrations of most elements in ooze from Hole 466 are evident from Table 8; differences are most noticeable for $\mathrm{Fe}, \mathrm{Na}, \mathrm{Ti}, \mathrm{Co}$, $\mathrm{Cu}, \mathrm{Mn}, \mathrm{Mo}, \mathrm{Ni}, \mathrm{V}$, and $\mathrm{Zr}$.

Unit II consists of olive-gray chalk and limestone containing up to $8.1 \%$ organic carbon; these are equivalent to the organic-carbon-rich, olive laminated limestone of Unit II, Hole 465A. Unfortunately, recovery of the rocks in Unit II was so poor that not enough samples could be collected to characterize the geochemistry of this unit.

\section{ACKNOWLEDGMENTS}

I am grateful to J. R. Herring and J. M. McNeal for helpful reviews of the manuscript. G. H. Harrach provided valuable assistance with computer graphics for the down-hole plots of element concentration. 
Table 3. Chemical analyses of samples from Hole 464 .

\begin{tabular}{|c|c|c|c|c|c|c|c|c|c|c|c|c|c|c|c|c|}
\hline Sample & $\begin{array}{l}\text { Site-Core-Section, } \\
\text { Interval (cm) }\end{array}$ & $\begin{array}{l}\text { Sub-bottom } \\
\text { Depth } \\
\text { (m) }\end{array}$ & $\underset{(\%: 0)}{\mathrm{SiO}_{2}-\mathrm{S}}$ & $\begin{array}{c}\mathrm{SiO}_{2}-\mathrm{xrf} \\
(\%)\end{array}$ & $\underset{(\%)}{\mathrm{Al}_{2} \mathrm{O}_{3}-\mathrm{S}}$ & $\begin{array}{c}\mathrm{Al}_{2} \mathrm{O}_{3}-\mathrm{xrf} \\
(\%)\end{array}$ & $\underset{(\%)}{\mathrm{Fe}_{2} \mathrm{O}_{3}-\mathrm{S}}$ & $\begin{array}{c}\mathrm{Fe}_{2} \mathrm{O}_{3} \cdot \mathrm{xrf} \\
\left(\%_{0}\right)\end{array}$ & $\begin{array}{c}\mathrm{MgO}-\mathrm{swc} \\
\left(\%_{0}\right)\end{array}$ & $\begin{array}{c}\mathrm{CaO}-\mathrm{S} \\
(\%)\end{array}$ & $\begin{array}{c}\mathrm{CaO}-\mathrm{xrf} \\
(\%)\end{array}$ & $\begin{array}{c}\mathrm{Na}_{2} \mathrm{O}-\mathrm{swc} \\
(\%)\end{array}$ & $\begin{array}{c}\mathrm{K}_{2} \mathrm{O}-\mathrm{S} \\
(\%)\end{array}$ & $\underset{(\%)}{\mathrm{K}_{2} \mathrm{O}-\mathrm{xrf}}$ & $\begin{array}{c}\mathrm{TiO}_{2}-\mathrm{S} \\
(\%)\end{array}$ & $\begin{array}{c}\mathrm{TiO}_{2} \text {-xrf } \\
(\%)\end{array}$ \\
\hline 40022070 & $464-2-2,70$ & 5.70 & 27.8 & 50 & 3.40 & 9.6 & 2.14 & 3.80 & 1.79 & 4.48 & 12.0 & 1.7270 & 2.05 & 2.30 & 0.138 & 0.40 \\
\hline 40022071 & $464-2-2,70$ & 5.70 & 34.2 & so & 4.72 & 9.6 & 2.86 & 3.80 & 2.00 & 6.72 & 12.0 & 0.7019 & 2.41 & 2.30 & 0.285 & 0.40 \\
\hline 40032138 & $464-3-2,138$ & 14.38 & 36.4 & 55 & 4.16 & 7.7 & 2.14 & 2.70 & 1.51 & 6.72 & 12.0 & 0.3023 & 2.17 & 1.90 & 0.210 & 0.30 \\
\hline 40042070 & $464-4-2,70$ & 24.70 & 38.5 & 56 & 7.37 & 12.0 & 4.29 & 5.30 & 2.29 & 2.38 & 2.9 & 0.7525 & 3.37 & 2.90 & 0.300 & 0.53 \\
\hline 40052020 & $464-5-2,20$ & 33.70 & 36.4 & 55 & 6.99 & 13.0 & 4.43 & 5.70 & 2.13 & 1.08 & 1.2 & 0.9777 & 3.01 & 3.00 & 0.270 & 0.58 \\
\hline 40052021 & $464-5-2,21$ & 33.70 & 6.2 & 55 & 1.89 & 13.0 & 0.80 & 5.90 & 2.29 & 32.18 & 1.2 & 0.6525 & 0.42 & 3.00 & 0.113 & 0.60 \\
\hline 40062082 & $464-6-2,82$ & 43.82 & 32.1 & 50 & 9.26 & 17.0 & 6.72 & 11.00 & 2.70 & 1.54 & 1.9 & 2.9510 & 5.54 & 4.20 & 0.465 & 1.40 \\
\hline 40062083 & $464-6-2,82$ & 43.82 & 27.8 & so & 6.42 & 16.0 & 5.72 & 11.00 & 2.61 & 1.32 & 1.9 & 0.8259 & 4.34 & 4.20 & 0.390 & 1.40 \\
\hline 40072010 & $464-7-2,10$ & 51.10 & 30.0 & 49 & 6.80 & 13.0 & 8.58 & 14.00 & 3.22 & 0.67 & 0.7 & 1.2264 & 5.18 & 4.30 & 0.615 & 2.30 \\
\hline 40082040 & $464-8-2,40$ & 62.40 & 27.8 & 48 & 5.29 & 13.0 & 7.29 & 13.00 & 2.81 & 1.40 & 1.4 & 1.2514 & 6.99 & 5.40 & 0.495 & 1.90 \\
\hline 40091110 & $464-9-1,110$ & 71.10 & 9.0 & 49 & 1.38 & 13.0 & 22.88 & 14.00 & 1.97 & 1.05 & 0.6 & 0.1771 & 0.89 & 4.40 & 0.053 & 2.30 \\
\hline 40102070 & $464-10-2,70$ & 81.70 & 34.2 & 53 & 4.53 & 10.0 & 4.72 & 6.80 & 0.02 & 3.36 & 6.0 & 0.0001 & 2.53 & 2.70 & 0.210 & 0.50 \\
\hline 40102071 & $464-10-2,70$ & 81.74 & $>72.7$ & 95 & 0.38 & 2.0 & 0.53 & 0.30 & 2.92 & 0.77 & 1.1 & 1.2009 & 0.18 & 0.20 & $<0.010$ & $<0.05$ \\
\hline 40111071 & $464-11-1,71$ & 89.71 & $>72.7$ & 86 & 0.53 & 2.0 & 0.56 & 0.50 & 0.43 & 4.06 & 8.0 & 0.1176 & 0.28 & 0.30 & 0.017 & 0.06 \\
\hline 40138009 & $464-13-8,9$ & 108.09 & 47.1 & 69 & 0.28 & 1.0 & 0.64 & 0.79 & 0.57 & 4.34 & 17.0 & 0.0951 & 0.28 & 0.45 & 0.013 & $<0.05$ \\
\hline
\end{tabular}

Note: Analyses were by X-ray fluorescence (xrf), semiquantitative optical emission spectroscopy (S), or atomic absorption (aa); analytical values for Mg and Na by atomic absorption were corrected for interstitial sea water (swc; see text for method of correction).

\section{REFERENCES}

Brongersma-Sanders, M., 1965. Metals of Kupferschiefer supplied by normal seawater. Geol. Rundschau, 55:365-375.

Burns, R. G., and Brown, B. A., 1972. Nucleation and mineralogical controls on the composition of manganese nodules. In Horn, D. R. (Ed.), Ferromanganese Deposits on the Ocean Floor: Washington (National Science Foundation), pp. 51-61.

Burns, R. G., and Burns, V. M., 1977. Mineralogy. In Glasby, G. P. (Ed.), Marine Manganese Deposits: Amsterdam (Elsevier), pp. $185-248$.

Calvert, S. E., and Price, N. B., 1970. Minor metal contents of recent organic-rich sediments off South West Africa. Nature, 277: 593-595.

Chester, R., Griffiths, A., and Stoner, J. H., 1978. Minor metal content of surface seawater particulates and organic-rich shelf sediments. Nature, 275:308-309.

Holland, H. D., 1979. Metals in black shales-a reassessment. Econ. Geol., 74:1676-1680.

Martin, J. H., and Knauer, G. A., 1973. The elemental composition of plankton. Geochim. Cosmochim. Acta, 37:1639-1653.

Miesch, A. T., 1976. Geochemical survey of Missouri-methods of sampling, laboratory analysis, and statistical reduction of data. U.S. Geol. Survey Prof. Paper, 954-A.
Turekian, K. K., 1964. The marine geochemistry of strontium. Geochim. Cosmochim. Acta, 28:1479-1496.

Varentsov, I. M., and Pronina, N. V., 1973. On the study of mechanisms of iron-manganese ore formation in Recent basins: the experimental data on nickel and cobalt. Mineral Deposita, $8: 161-178$.

Vine, J. D., and Tourtelot, E. B., 1970. Geochemistry of black shale deposits-a summary report. Econ. Geol., 65:253-272.

Volkov, I. I., and Fomina, L. S., 1974. Influence of organic materials and processes of sulfide formation on distribution of some trace elements in deep-water sediments of Black Sea. In Degens, E. T., and Ross, D. A. (Eds.), The Black Sea-Geology, Chemistry, and Biology: Am. Assoc. Petrol. Geol. Mem., 20:457-476.

Wangersky, P. J., and Joensuu, Oiva, 1964. Strontium, magnesium, and manganese in fossil foraminiferal carbonates. J. Geol., $72: 477-483$

1967. The fractionation of carbonate deep-sea cores. $J$ Geol., 75:148-177.

Wedepohl, K. H., 1964. Untersuchungen am Kupferschiefur in Nordwest deutschland; ein Beitrag zur Deutung der Genese bituminoger Sediment. Geochim. Cosmochim. Acta, 28:305. 
Table 3. (Continued).

\begin{tabular}{|c|c|c|c|c|c|c|c|c|c|c|c|c|c|c|c|c|c|c|c|c|c|}
\hline $\begin{array}{c}\text { B-S } \\
(\mathrm{ppm})\end{array}$ & $\begin{array}{l}\mathrm{Ba} \cdot \mathrm{S} \\
(\mathrm{ppm})\end{array}$ & $\begin{array}{c}\mathrm{Be}-\mathrm{S} \\
(\mathrm{ppm})\end{array}$ & $\begin{array}{c}\mathrm{Co}-\mathrm{S} \\
(\mathrm{ppm})\end{array}$ & $\underset{(\mathrm{ppm}-\mathrm{S})}{\mathrm{Cr}}$ & $\begin{array}{c}\mathrm{Cu}-\mathrm{S} \\
(\mathrm{ppm})\end{array}$ & $\underset{(\mathrm{ppm})}{\mathrm{Ga}-\mathrm{S}}$ & $\begin{array}{l}\text { La-S } \\
(\mathrm{ppm})\end{array}$ & $\begin{array}{l}\text { Li-aa } \\
\text { (ppm) }\end{array}$ & $\begin{array}{l}\mathrm{Mn}-\mathrm{S} \\
(\mathrm{ppm})\end{array}$ & $\underset{(\mathrm{ppm})}{\mathrm{Mo-S}}$ & $\begin{array}{c}\mathrm{Ni}-\mathrm{S} \\
(\mathrm{ppm})\end{array}$ & $\begin{array}{c}\mathrm{Pb}-\mathrm{S} \\
(\mathrm{ppm})\end{array}$ & $\begin{array}{l}\text { Rb-aa } \\
\text { (ppm) }\end{array}$ & $\begin{array}{l}\text { Sc-S } \\
\text { (ppm) }\end{array}$ & $\begin{array}{c}\mathrm{Sn}-\mathrm{S} \\
(\mathrm{ppm})\end{array}$ & $\underset{(\mathrm{ppm})}{\mathrm{Sr}-\mathrm{S}}$ & $\underset{\text { (ppm) }}{\mathrm{V}-\mathrm{S}}$ & $\underset{\text { (ppm) }}{\text { Y-S }}$ & $\begin{array}{c}\mathrm{Yb}-\mathrm{S} \\
(\mathrm{ppm})\end{array}$ & $\underset{\text { (ppm) }}{\mathrm{Zn}-\mathrm{S}}$ & $\underset{(\mathrm{ppm})}{\mathrm{Zr}-\mathrm{S}}$ \\
\hline 57.0 & 2,100 & 1.3 & 13.0 & 18.0 & 58.0 & 12.0 & 26 & 37 & 1,800 & $<2.2$ & 83.0 & 12.0 & 65 & 10.0 & 1.6 & 430 & 49.0 & 20.0 & 2.30 & 110 & 80.0 \\
\hline 73.0 & 2,900 & 1.6 & 20.0 & 22.0 & 77.0 & 16.0 & 42 & 37 & 2,100 & $<2.2$ & 110.0 & 15.0 & 67 & 15.0 & 2.1 & 690 & 69.0 & 29.0 & 3.40 & 93 & 110.0 \\
\hline 76.0 & 2,900 & 1.5 & 21.0 & 15.0 & 48.0 & 12.0 & 31 & 31 & 1,100 & $<2.2$ & 95.0 & 17.0 & 51 & 14.0 & 2.0 & 660 & 42.0 & 21.0 & 2.60 & 65 & 68.0 \\
\hline 80.0 & 3,100 & 2.4 & 21.0 & 33.0 & 97.0 & 22.0 & 50 & 46 & 1,500 & $<2.2$ & 110.0 & 19.0 & 69 & 18.0 & 3.7 & 380 & 83.0 & 39.0 & 4.10 & 72 & 150.0 \\
\hline 91.0 & $>3,200$ & 2.9 & 47.0 & 28.0 & 90.0 & 18.0 & 54 & 61 & 6,900 & $<2.2$ & 170.0 & 22.0 & 100 & 18.0 & 3.8 & 350 & 75.0 & 51.0 & 4.60 & 71 & 140.0 \\
\hline$<4.6$ & 160 & $<1.0$ & 1.3 & 7.8 & 3.1 & 3.3 & 58 & 58 & 350 & 5.0 & 4.5 & $<6.8$ & 80 & 4.0 & $<1.5$ & 550 & 50.0 & 11.0 & 1.10 & $<10$ & 220.0 \\
\hline 87.0 & 350 & 2.0 & 40.0 & 48.0 & 260.0 & 19.0 & 73 & 55 & 8,500 & 8.6 & 150.0 & 31.0 & 87 & 19.0 & $<1.5$ & 210 & 84.0 & 79.0 & 11.00 & 110 & 90.0 \\
\hline 75.0 & 330 & 1.7 & 32.0 & 30.0 & 220.0 & 15.0 & 63 & 48 & 7,300 & 8.4 & 110.0 & 110.0 & 68 & 17.0 & $<1.5$ & 160 & 73.0 & 74.0 & 8.60 & 95 & 120.0 \\
\hline 90.0 & 87 & 1.3 & 21.0 & 39.0 & 70.0 & 11.0 & 23 & 55 & 2,800 & $<2.2$ & 68.0 & $<6.8$ & 43 & 15.0 & $<1.5$ & 92 & 55.0 & 21.0 & 2.40 & 99 & 66.0 \\
\hline 87.0 & 130 & $<1.0$ & 21.0 & 120.0 & 96.0 & 12.0 & 21 & 48 & 3,500 & $<2.2$ & 80.0 & $<6.8$ & 53 & 11.0 & $<1.5$ & 89 & 61.0 & 19.0 & 2.90 & 83 & 53.0 \\
\hline 92.0 & 510 & 4.2 & 31.0 & 6.2 & 890.0 & 5.9 & 180 & 18 & 46,000 & 74.0 & 150.0 & 75.0 & 25 & 10.0 & $<1.5$ & 520 & 200.0 & 98.0 & 8.60 & 350 & 150.0 \\
\hline 94.0 & 510 & 1.3 & 55.0 & 14.0 & 400.0 & 10.0 & 260 & 67 & 14,000 & 2.6 & 170.0 & 20.0 & 53 & 24.0 & 5.6 & 330 & 42.0 & 220.0 & 21.00 & 210 & 87.0 \\
\hline 81.0 & 140 & $<1.0$ & 3.4 & $<1.0$ & 34.0 & $<1.5$ & 15 & 12 & 780 & $<2.2$ & 11.0 & $<6.8$ & $<10$ & 1.7 & $<1.5$ & 19 & 5.8 & 18.0 & 1.20 & 18 & 11.0 \\
\hline 19.0 & 190 & $<1.0$ & $<1.0$ & 6.0 & 7.7 & $<1.5$ & $<10$ & 13 & 77 & $<2.2$ & 3.3 & $<6.8$ & $<10$ & 1.4 & $<1.5$ & 120 & 5.3 & 5.3 & 0.42 & 22 & 7.1 \\
\hline 13.0 & 130 & $<1.0$ & $<1.0$ & 11.0 & 59.0 & $<1.5$ & $<10$ & 10 & 370 & $<2.2$ & 9.0 & $<6.8$ & $<10$ & 1.8 & $<1.5$ & 240 & 7.3 & 7.3 & 0.56 & 44 & 14.0 \\
\hline
\end{tabular}

Table 4. Summary statistics for element concentrations in 12 samples of brown clay from Lithologic Unit II, Hole 464.

\begin{tabular}{lccc}
\hline Element & $\begin{array}{c}\text { Observed } \\
\text { Range }\end{array}$ & $\begin{array}{c}\text { Arithmetic } \\
\text { Mean }\end{array}$ & $\begin{array}{c}\text { Standard } \\
\text { Deviation }\end{array}$ \\
\hline $\mathrm{Si}(\%)$ & $2.9-18$ & 13 & 4.9 \\
$\mathrm{Al}$ & $4.1-8.9$ & 6.5 & 1.4 \\
$\mathrm{Fe}$ & $0.56-16$ & 4.2 & 4.0 \\
$\mathrm{Mn}$ & $0.35-4.6$ & 0.80 & 1.3 \\
$\mathrm{Mg}$ & $0.11-0.34$ & 0.22 & 0.084 \\
$\mathrm{Ca}$ & $0.43-8.6$ & 3.2 & 3.4 \\
$\mathrm{Na}$ & $0.89-2.8$ & 1.9 & 0.70 \\
$\mathrm{~K}$ & $1.6-4.5$ & 2.8 & 0.89 \\
$\mathrm{Ti}$ & $0.035-0.41$ & 0.20 & 0.11 \\
$\mathrm{~B}(\mathrm{ppm})$ & $3.0-94$ & 75 & 25 \\
$\mathrm{Ba}$ & $87-4000$ & 140 & 150 \\
$\mathrm{Be}$ & $0.70-4.2$ & 1.8 & 0.98 \\
$\mathrm{Co}$ & $13-55$ & 27 & 15 \\
$\mathrm{Cr}$ & $6.2-120$ & 32 & 31 \\
$\mathrm{Cu}$ & $3.1-890$ & 190 & 250 \\
$\mathrm{Ga}$ & $3.3-22$ & 13 & 5.6 \\
$\mathrm{La}$ & $21-260$ & 73 & 73 \\
$\mathrm{Li}$ & $18-67$ & 47 & 14 \\
$\mathrm{Mo}$ & $1.5-74$ & 9.1 & 21 \\
$\mathrm{Ni}$ & $4.5-170$ & 110 & 48 \\
$\mathrm{~Pb}$ & $5.0-110$ & 28 & 32 \\
$\mathrm{Rb}$ & $25-100$ & 63 & 20 \\
$\mathrm{Sc}$ & $4.0-24$ & 15 & 5.3 \\
$\mathrm{Sr}$ & $89-690$ & 370 & 210 \\
$\mathrm{~V}$ & $42-200$ & 74 & 43 \\
$\mathrm{Y}$ & $11-220$ & 57 & 59 \\
$\mathrm{Yb}$ & $1.1-21$ & 6.3 & 5.8 \\
$\mathrm{Zn}$ & $7.0-350$ & 110 & 88 \\
$\mathrm{Zr}$ & $53-220$ & 110 & 48 \\
\hline
\end{tabular}


\&
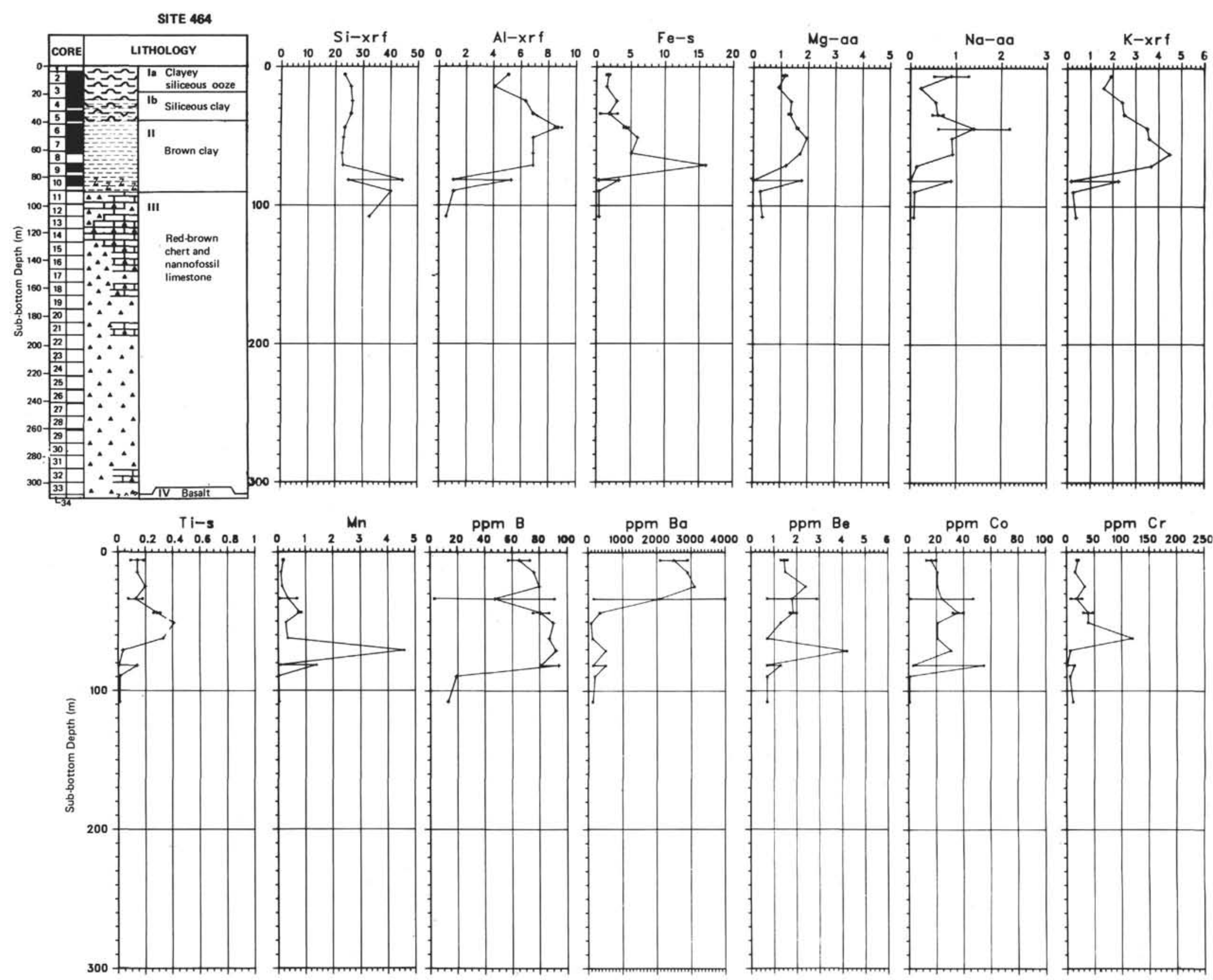

ppm Ba
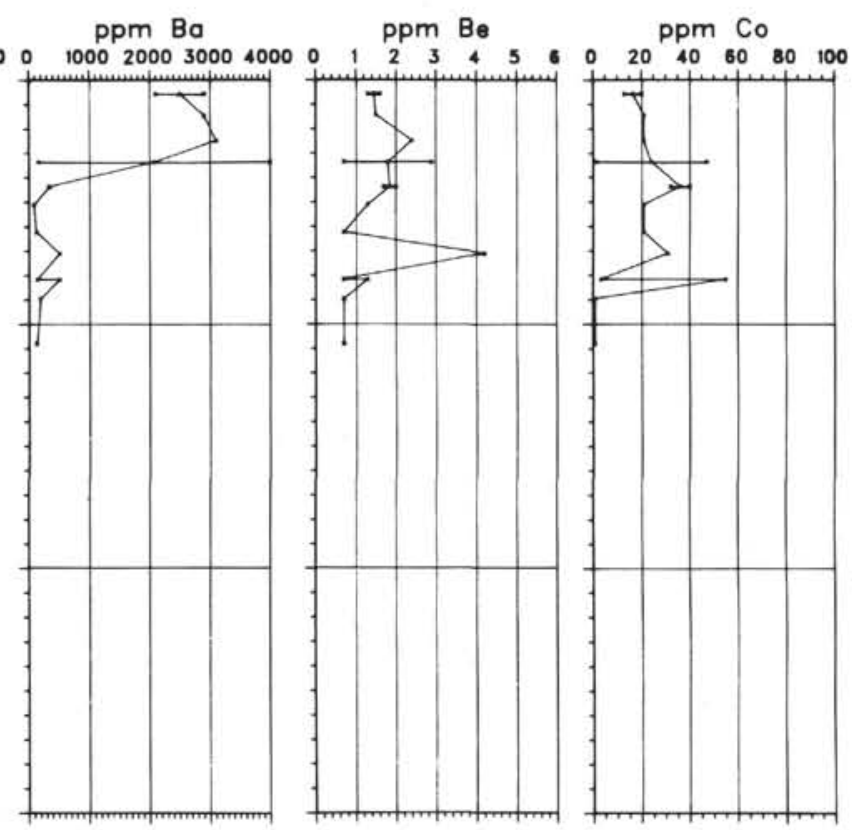

$\mathrm{Ppm} \mathrm{Cr}$

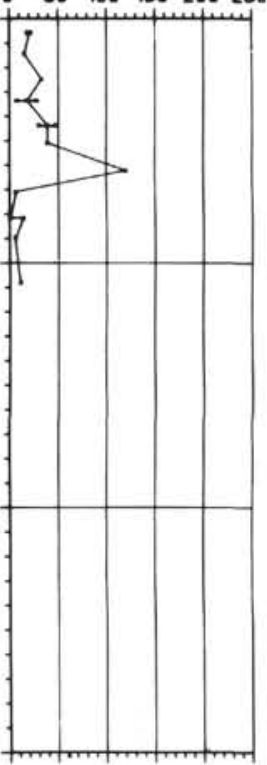




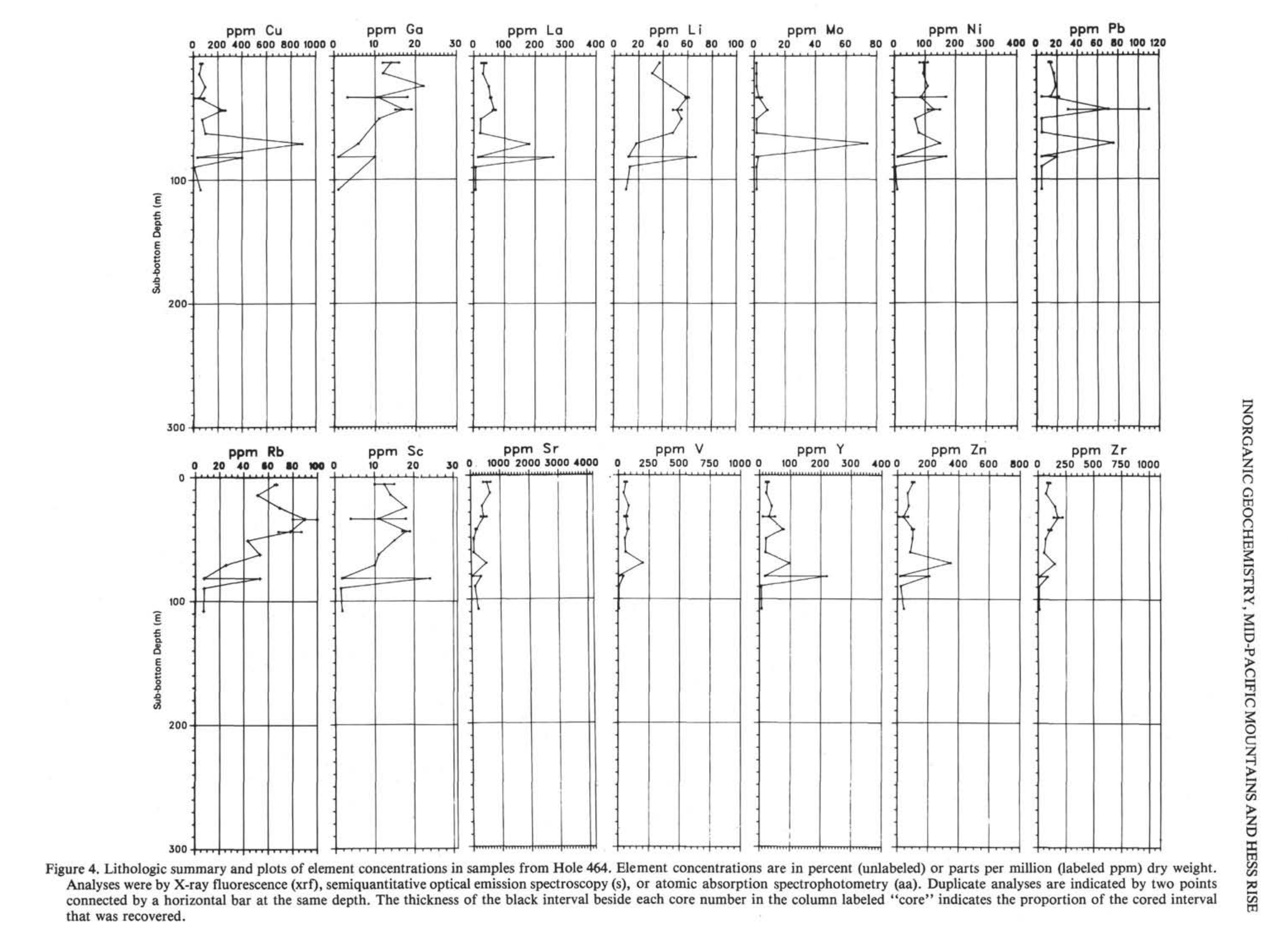


Table 5. Chemical analyses of samples from Holes 465 and 465A.

\begin{tabular}{|c|c|c|c|c|c|c|c|c|c|c|c|c|c|c|c|}
\hline Sample & $\begin{array}{l}\text { Hole-Core-Section, } \\
\text { Interval }(\mathrm{cm})\end{array}$ & $\begin{array}{l}\text { Sub-bottom } \\
\text { Depth } \\
\text { (m) }\end{array}$ & $\begin{array}{c}\mathrm{SiO}_{2}-\mathrm{S} \\
(\%)\end{array}$ & $\underset{(\%)}{\mathrm{SiO}_{2}-\mathrm{xrf}}$ & $\begin{array}{c}\mathrm{Al}_{2} \mathrm{O}_{3}-\mathrm{S} \\
(\%)\end{array}$ & $\begin{array}{c}\mathrm{Al}_{2} \mathrm{O}_{3} \text {-xrf } \\
(\%)\end{array}$ & $\begin{array}{c}\mathrm{Fe}_{2} \mathrm{O}_{3}-\mathrm{S} \\
(\%)\end{array}$ & $\begin{array}{c}\mathrm{Fe}_{2} \mathrm{O}_{3} \cdot \mathrm{xrf} \\
(\%)\end{array}$ & $\begin{array}{c}\mathrm{MgO}-\mathrm{swc} \\
(\%)\end{array}$ & $\underset{(\%)}{\mathrm{CaO}-\mathrm{S}}$ & $\begin{array}{c}\mathrm{CaO}-x \mathrm{rf} \\
(\%)\end{array}$ & $\begin{array}{c}\mathrm{Na}_{2} \mathrm{O}-5 w c \\
(\%)\end{array}$ & $\underset{(\%)}{\mathrm{K}_{2} \mathrm{O}-\mathrm{S}}$ & $\begin{array}{c}\mathrm{K}_{2} \mathrm{O}-\mathrm{xrf} f \\
(\%)\end{array}$ & $\underset{(\%)}{\mathrm{TiO}_{2}-\mathrm{S}}$ \\
\hline 50011026 & $465-1-1,26$ & 0.26 & 2.57 & 6.0 & 0.85 & 1.0 & 0.815 & 0.51 & 0.294 & 40.58 & 60.0 & 0.2507 & 0.49 & 0.20 & 0.035 \\
\hline 50011027 & $465-1-1,26$ & 0.26 & 3.64 & 5.7 & 1.17 & 1.0 & 0.829 & 0.50 & 0.356 & $>44.77$ & 58.0 & 0.3257 & 0.42 & 0.20 & 0.050 \\
\hline 50021060 & $465-2-1,60$ & 1.60 & 2.78 & 6.0 & 1.10 & 2.0 & 0.743 & 0.40 & 0.249 & 41.98 & 62.0 & 0.1180 & 0.47 & 0.40 & 0.038 \\
\hline 50024060 & $465-2-4,60$ & 6.10 & 0.94 & 3.0 & 0.19 & 0.9 & 0.130 & $<0.05$ & 0.300 & $>44.77$ & 64.0 & 0.2404 & 0.29 & 0.04 & 0.017 \\
\hline 50032060 & $465-3-2,60$ & 12.60 & 0.16 & 15.0 & $<0.06$ & 4.0 & 0.051 & 0.81 & 0.108 & 32.18 & 49.0 & 0.0001 & 0.18 & 0.55 & $<0.010$ \\
\hline 50043100 & $465-4-3,100$ & 24.00 & 0.18 & 1.0 & $<0.06$ & $<0.5$ & 0.229 & $<0.05$ & 0.173 & 41.98 & 65.0 & 0.0929 & 0.18 & $<0.03$ & $<0.010$ \\
\hline 50053066 & $465-5-3,66$ & 33.16 & 0.39 & 1.0 & $<0.06$ & $<0.5$ & 0.061 & $<0.05$ & 0.111 & 34.98 & 65.0 & 0.1255 & 0.19 & $<0.03$ & $<0.010$ \\
\hline 50061100 & $465-6-1,100$ & 40.00 & 0.30 & 2.0 & $<0.06$ & 0.7 & 0.093 & $<0.05$ & 0.156 & 29.38 & 64.0 & 0.1155 & 0.19 & $<0.03$ & $<0.010$ \\
\hline 50061101 & $465-6-1,100$ & 40.00 & 0.41 & 2.0 & $<0.06$ & $<0.5$ & 0.103 & $<0.05$ & 0.098 & 32.18 & 65.0 & 0.0001 & 0.20 & $<0.03$ & $<0.010$ \\
\hline 50105100 & $465-10-5,100$ & 84.00 & 0.32 & 4.0 & $<0.06$ & 0.8 & 0.049 & $<0.05$ & 0.149 & 29.38 & 65.0 & 0.0554 & 0.17 & 0.09 & $<0.010$ \\
\hline 51011037 & $465 \mathrm{~A}-1-1,37$ & 39.37 & 0.39 & 2.0 & $<0.06$ & $<0.5$ & 0.056 & $<0.05$ & 0.088 & 29.38 & 64.0 & 0.0001 & 0.19 & $<0.03$ & $<0.010$ \\
\hline 51033011 & $465 \mathrm{~A}-3-3,11$ & 61.11 & 0.36 & 2.0 & $<0.06$ & $<0.5$ & 0.064 & $<0.05$ & 0.489 & 32.18 & 65.0 & 0.3505 & 0.18 & $<0.03$ & $<0.010$ \\
\hline 51033088 & $465 \mathrm{~A}-3-3,88$ & 61.88 & 1.50 & 4.0 & 0.32 & 1.0 & 0.529 & 0.10 & 0.218 & $>44.77$ & 61.0 & 0.0001 & 0.36 & 0.06 & 0.014 \\
\hline 51033137 & $465 A-3-3,137$ & 62.37 & 5.99 & 11.0 & 1.49 & 3.0 & 2.288 & 2.90 & 1.011 & 27.98 & 50.0 & 0.1259 & 0.47 & 0.30 & 0.078 \\
\hline 51034014 & $465 \mathrm{~A}-3-4,14$ & 62.64 & 0.34 & 3.0 & $<0.06$ & 0.7 & 0.097 & $<0.05$ & 0.211 & 32.18 & 65.0 & 0.0255 & 0.22 & $<0.03$ & $<0.010$ \\
\hline 51093048 & $465 \mathrm{~A}-9-3,48$ & 118.48 & 0.56 & 2.0 & $<0.06$ & $<0.5$ & 0.040 & $<0.05$ & 0.190 & $>44.77$ & 64.0 & 0.1580 & 0.22 & $<0.03$ & $<0.010$ \\
\hline 51102030 & $465 \mathrm{~A}-10-2,30$ & 126.30 & 0.13 & 2.0 & $<0.06$ & $<0.5$ & 0.033 & $<0.05$ & 0.117 & 37.78 & 65.0 & 0.0001 & 0.19 & 0.08 & $<0.010$ \\
\hline 51102031 & $465 \mathrm{~A}-10-2,30$ & 126.30 & 0.13 & 2.0 & $<0.06$ & 0.7 & 0.021 & $<0.05$ & 0.108 & 27.98 & 66.0 & 0.0156 & 0.17 & $<0.03$ & $<0.010$ \\
\hline 51112012 & $465 \mathrm{~A}-11-2,12$ & 135.62 & 0.14 & 1.0 & $<0.06$ & $<0.5$ & 0.037 & $<0.05$ & 0.120 & 36.38 & 64.0 & 0.0001 & 0.18 & $<0.03$ & $<0.010$ \\
\hline 51122013 & $465 \mathrm{~A}-12-2,13$ & 145.13 & 0.16 & 6.8 & $<0.06$ & 2.0 & 0.046 & 0.20 & 0.088 & 32.18 & 57.0 & 0.0001 & 0.19 & 0.30 & $<0.010$ \\
\hline 51151100 & $465 \mathrm{~A} \cdot 15-1,100$ & 173.00 & 0.73 & 2.0 & $<0.06$ & $<0.5$ & 0.083 & $<0.05$ & 0.131 & 39.18 & 65.0 & 0.0630 & 0.22 & $<0.03$ & $<0.010$ \\
\hline 51162030 & $465 \mathrm{~A}-16-2,30$ & 183.30 & 0.15 & 2.0 & $<0.06$ & 0.7 & 0.023 & $<0.05$ & 0.137 & 30.78 & 65.0 & 0.0754 & 0.17 & $<0.03$ & $<0.010$ \\
\hline 51171110 & $465 \mathrm{~A}-17-1,110$ & 192.10 & 0.43 & 30.0 & $<0.06$ & 8.6 & 0.110 & 1.70 & 0.168 & 30.78 & 32.0 & 0.0001 & 0.27 & 1.30 & $<0.010$ \\
\hline 51181050 & $465 \mathrm{~A}-18-1,50$ & 201.00 & 0.12 & 2.0 & $<0.06$ & 0.7 & 0.019 & $<0.05$ & 0.078 & 32.18 & 65.0 & 0.0001 & 0.18 & $<0.03$ & $<0.010$ \\
\hline 51192127 & $465 \mathrm{~A}-19-2,127$ & 212.77 & 0.15 & 2.0 & $<0.06$ & $<0.5$ & 0.021 & $<0.05$ & 0.107 & 30.78 & 65.0 & 0.0001 & 0.18 & $<0.03$ & $<0.010$ \\
\hline 51201014 & $465 \mathrm{~A}-20-1,14$ & 219.64 & 10.27 & 4.0 & $<0.06$ & 0.9 & 0.061 & $<0.05$ & 0.099 & $>44.77$ & 66.0 & 0.0001 & 0.19 & 0.08 & $<0.010$ \\
\hline 51214067 & $465 \mathrm{~A}-21-4,67$ & 234.17 & 0.60 & 3.0 & $<0.06$ & 1.0 & 0.136 & $<0.05$ & 0.213 & 27.98 & 63.0 & 0.0954 & 0.24 & $<0.03$ & $<0.010$ \\
\hline 51261075 & $465 \mathrm{~A}-26-1,75 \mathrm{ol}$ & 277.25 & 0.49 & 2.0 & $<0.06$ & $<0.5$ & 0.117 & $<0.05$ & 0.492 & 40.58 & 65.0 & 0.0301 & 0.19 & $<0.03$ & $<0.010$ \\
\hline 51272048 & $465 \mathrm{~A}-27-2,48 \mathrm{ol}$ & 287.98 & 0.88 & 3.0 & 0.28 & 1.0 & 0.229 & $<0.05$ & 0.607 & $>44.77$ & 63.0 & 0.0201 & 0.29 & 0.10 & 0.029 \\
\hline 51282011 & $465 \mathrm{~A}-28-2,10 \mathrm{ol}$ & 297.10 & 7.49 & 10.0 & 2.65 & 3.0 & 0.872 & 0.56 & 0.983 & 43.37 & 54.0 & 0.4850 & 0.45 & 0.20 & 0.165 \\
\hline 51282019 & $465 \mathrm{~A}-28-2,19 \mathrm{~g}$ & 297.19 & 14.76 & 23.0 & 4.35 & 7.5 & 1.573 & 1.80 & 1.321 & 26.58 & 41.0 & 0.7679 & 1.06 & 0.85 & 0.360 \\
\hline 51291109 & $465 \mathrm{~A}-29-1,109 \mathrm{ol}$ & 306.09 & 5.13 & 8.0 & 1.79 & 3.0 & 2.288 & 2.30 & 0.739 & 32.18 & 56.0 & 0.3051 & 0.23 & $<0.03$ & 0.240 \\
\hline 51291117 & $465 \mathrm{~A}-29-1,117 \mathrm{~g}$ & 306.17 & 16.47 & 23.0 & 5.48 & 7.5 & 1.859 & 2.00 & 1.533 & 25.19 & 40.0 & 0.7503 & 0.63 & 0.43 & 0.360 \\
\hline 51301059 & $465 \mathrm{~A}-30-1,59 \mathrm{ol}$ & 315.09 & 4.49 & 7.2 & 1.79 & 2.0 & 0.815 & 0.62 & 0.567 & $>44.77$ & 58.0 & 0.2552 & 0.45 & 0.20 & 0.080 \\
\hline 51311013 & $465 \mathrm{~A}-31-1,13 \mathrm{ol}$ & 324.13 & 0.51 & 2.0 & $<0.06$ & 0.5 & 0.106 & $<0.05$ & 0.518 & $>44.77$ & 65.0 & 0.0501 & 0.19 & $<0.03$ & $<0.010$ \\
\hline 51321032 & $465 \mathrm{~A}-32-1,32 \mathrm{ol}$ & 333.82 & 7.06 & 14.0 & 2.08 & 4.0 & 1.087 & 1.00 & 1.289 & 26.58 & 52.0 & 0.4651 & 0.30 & 0.09 & 0.065 \\
\hline 51321039 & $465 \mathrm{~A}-32-1,39 \mathrm{ol}$ & 333.89 & 10.05 & 12.0 & 2.27 & 3.0 & 0.243 & $<0.05$ & 0.349 & $>44.77$ & 53.0 & 0.5253 & 1.02 & 0.94 & 0.032 \\
\hline 51321064 & $465 \mathrm{~A}-32-1,64 \mathrm{Ol}$ & 334.14 & 1.39 & 4.0 & 0.38 & 1.0 & 0.343 & 0.09 & 0.393 & 39.18 & 62.0 & 0.0001 & 0.34 & 0.06 & 0.015 \\
\hline 51321085 & $465 \mathrm{~A}-32-1,85 \mathrm{ol}$ & 334.35 & 2.14 & 4.0 & 0.64 & 0.8 & 0.415 & 0.08 & 0.359 & 39.18 & 53.0 & 0.1503 & 0.34 & 0.10 & 0.039 \\
\hline 51331021 & 465A-33-1, 21ol & 343.21 & 1.26 & 3.0 & 0.36 & 0.9 & 0.200 & $<0.05$ & 0.579 & $>44.77$ & 65.0 & 0.1876 & 0.24 & $<0.03$ & 0.011 \\
\hline 51331022 & 465A-33-1, 21ol & 343.21 & 1.01 & 3.0 & 0.26 & 0.7 & 0.172 & $<0.05$ & 0.613 & $>44.77$ & 64.0 & 0.0976 & 0.20 & $<0.03$ & 0.011 \\
\hline 51331029 & $465 \mathrm{~A}-33-1,29 \mathrm{~g}$ & 343.29 & 15.83 & 23.0 & 4.53 & 6.6 & 1.859 & 1.40 & 1.894 & 25.19 & 38.0 & 1.1626 & 1.16 & 0.87 & 0.195 \\
\hline 51341010 & $465 \mathrm{~A}-34-1,10 \mathrm{ol}$ & 352.60 & 0.49 & 2.0 & $<0.06$ & 0.7 & 0.097 & $<0.05$ & 0.552 & 41.98 & 63.0 & 0.0001 & 0.19 & $<0.03$ & $<0.010$ \\
\hline 51341011 & $465 \mathrm{~A}-34-1,10 \mathrm{ol}$ & 352.60 & 0.53 & 2.0 & $<0.06$ & 0.6 & 0.122 & $<0.05$ & 0.522 & $>44.77$ & 64.0 & 0.0026 & 0.19 & $<0.03$ & $<0.010$ \\
\hline 51362062 & $465 \mathrm{~A}-36-2,62 \mathrm{Ol}$ & 373.62 & 0.81 & 2.0 & 0.19 & $<0.5$ & 0.214 & $<0.05$ & 0.751 & $>44.77$ & 63.0 & 0.0001 & 0.20 & $<0.03$ & $<0.010$ \\
\hline 51371104 & $465 \mathrm{~A}-37-1,104 \mathrm{ol}$ & 382.04 & 5.13 & 8.2 & 1.59 & 2.0 & 0.715 & 0.40 & 0.578 & 33.58 & 53.0 & 0.2878 & 0.69 & 0.60 & 0.093 \\
\hline 51371111 & $465 \mathrm{~A}-37-1,111 \mathrm{~g}$ & 382.11 & 17.97 & 2.0 & 4.72 & 0.7 & 1.430 & $<0.05$ & 2.282 & 19.59 & 65.0 & 1.6801 & 1.57 & $<0.03$ & 0.225 \\
\hline 51382129 & $465 \mathrm{~A}-38-2,129 \mathrm{~g}$ & 393.29 & 15.19 & 25.0 & 3.59 & 7.9 & 1.859 & 2.30 & 2.022 & 16.79 & 35.0 & 0.6754 & 1.19 & 1.00 & 0.255 \\
\hline 51382137 & $465 \mathrm{~A}-38-2,137 \mathrm{ol}$ & 393.37 & 0.83 & 3.0 & 0.19 & 1.0 & 0.127 & $<0.05$ & 0.670 & $>44.77$ & 65.0 & 0.0551 & 0.24 & $<0.03$ & 0.012 \\
\hline 51391111 & $465 \mathrm{~A}-39-1,111 \mathrm{ol}$ & 401.11 & 0.41 & 1.0 & $<0.06$ & $<0.5$ & 0.066 & $<0.05$ & 0.599 & 43.37 & 64.0 & 0.0001 & 0.20 & 0.08 & $<0.010$ \\
\hline 51401001 & $465 \mathrm{~A}-40-1,10 \mathrm{l}$ & 409.51 & 3.00 & 5.0 & 0.59 & 0.9 & 0.443 & 0.08 & 0.490 & $>44.77$ & 59.0 & 0.0753 & 0.30 & 0.10 & 0.023 \\
\hline 51401029 & $465 \mathrm{~A}-40-1,29 \mathrm{ol}$ & 409.79 & 3.00 & 5.5 & 0.79 & 1.0 & 0.386 & 0.08 & 0.534 & 33.58 & 57.0 & 0.1453 & 0.42 & 0.20 & 0.027 \\
\hline 51401044 & $465 \mathrm{~A}-40-1,44 \mathrm{ol}$ & 409.94 & 3.64 & 3.0 & 1.23 & 1.0 & 0.500 & $<0.05$ & 0.699 & 36.38 & 63.0 & 0.2152 & 0.51 & $<0.03$ & 0.033 \\
\hline 51401073 & $465 \mathrm{~A}-40-1,73 \mathrm{ol}$ & 410.23 & 4.49 & 7.8 & 1.47 & 2.0 & 0.686 & 0.40 & 0.940 & 36.38 & 55.0 & 0.3202 & 0.49 & 0.41 & 0.054 \\
\hline 51401104 & $465 \mathrm{~A}-40-1,104 \mathrm{ol}$ & 410.54 & 7.70 & 11.0 & 1.89 & 3.0 & 0.758 & 0.30 & 2.672 & 43.37 & 50.0 & 0.4926 & 0.77 & 0.66 & 0.089 \\
\hline 51401111 & $465 \mathrm{~A}-40-1,111$ & 410.61 & 10.91 & 2.0 & 3.21 & $<0.5$ & 1.029 & $<0.05$ & 1.788 & 37.78 & 67.0 & 0.6676 & 0.76 & $<0.03$ & 0.113 \\
\hline 51401113 & $465 \mathrm{~A}-40-1,113 \mathrm{ol}$ & 410.63 & 6.20 & 8.8 & 1.83 & 3.0 & 0.786 & 0.50 & 3.181 & 34.98 & 52.0 & 0.3926 & 0.48 & 0.30 & 0.039 \\
\hline 51401139 & $465 \mathrm{~A}-40-1,139$ & 410.89 & 29.95 & 46.0 & 4.35 & 13.0 & 1.716 & 2.60 & 4.449 & 5.32 & 14.0 & 2.3553 & 2.17 & 2.10 & 0.120 \\
\hline 51402001 & $465 \mathrm{~A}-40-2,1$ & 411.01 & 32.09 & 53.0 & 3.97 & 15.0 & 6.291 & 12.00 & 3.669 & 0.56 & 1.0 & 1.6902 & 1.45 & 1.70 & 0.062 \\
\hline 51402032 & $465 \mathrm{~A}-40-2,32$ & 411.32 & 12.19 & 14.0 & 2.08 & 4.0 & 24.305 & 24.00 & 1.290 & 7.14 & 15.0 & 0.0001 & 0.41 & 0.34 & 0.038 \\
\hline 51402056 & $465 \mathrm{~A}-40-2,56$ & 411.56 & 44.93 & 59.0 & 9.45 & 17.0 & 2.859 & 3.50 & 2.766 & 1.02 & 1.0 & 2.6677 & 3.80 & 3.98 & 0.270 \\
\hline 51402065 & $465 \mathrm{~A}-40-2,65$ & 411.65 & 47.06 & 59.0 & 7.94 & 17.0 & 2.002 & 2.70 & 3.178 & 0.38 & 0.6 & 2.9502 & 2.53 & 2.90 & 0.144 \\
\hline
\end{tabular}

Note: Analyses were by X-ray fluorescence (xrf), semiquantitative optical emission spectroscopy (S), or atomic absorption (aa); analytical values for $\mathrm{Mg}$ and $\mathrm{Na}$ by atomic absorption were corrected for interstitial sea water (swc; sec text for method of correction). Letter designations following intervals are: $\mathrm{B}$, sample of gray, massive limestone from Lithologic Unit II; ol, sample of olivine, laminated limestone from Lithologic Unit II. 
Table 5. (Continued).

\begin{tabular}{|c|c|c|c|c|c|c|c|c|c|c|c|c|c|c|c|c|c|c|c|c|}
\hline $\begin{array}{c}\mathrm{TiO}_{2} \text {-xrf } \\
(\%)\end{array}$ & $\begin{array}{c}\text { B-S } \\
(\mathrm{ppm})\end{array}$ & $\begin{array}{c}\mathrm{Ba}-\mathrm{S} \\
(\mathrm{ppm})\end{array}$ & $\begin{array}{c}\text { Co-S } \\
(\mathrm{ppm})\end{array}$ & $\begin{array}{c}\mathrm{Cr}-\mathrm{S} \\
(\mathrm{ppm})\end{array}$ & $\begin{array}{c}\mathrm{Cu}-\mathrm{S} \\
(\mathrm{ppm})\end{array}$ & $\begin{array}{c}\text { Ga-S } \\
(\mathrm{ppm})\end{array}$ & $\begin{array}{l}\text { La-S } \\
\text { (ppm) }\end{array}$ & $\begin{array}{c}\text { Li-aa } \\
(\mathrm{ppm})\end{array}$ & $\begin{array}{l}\mathrm{Mn}-\mathrm{S} \\
(\mathrm{ppm})\end{array}$ & $\begin{array}{l}\text { Mo-S } \\
(\mathrm{ppm})\end{array}$ & $\begin{array}{l}\mathrm{Ni}-\mathrm{S} \\
(\mathrm{ppm})\end{array}$ & $\begin{array}{l}\text { Rb-aa } \\
(\mathrm{ppm})\end{array}$ & $\begin{array}{c}\text { Sc-S } \\
(\mathrm{ppm})\end{array}$ & $\begin{array}{c}\text { Sn-S } \\
(\mathrm{ppm})\end{array}$ & $\begin{array}{c}\mathrm{Sr}-\mathrm{S} \\
(\mathrm{ppm})\end{array}$ & $\begin{array}{c}\text { V.S } \\
\text { (ppm) }\end{array}$ & $\begin{array}{c}Y-S \\
(\mathrm{ppm})\end{array}$ & $\begin{array}{l}\text { Yb-S } \\
(\mathrm{ppm})\end{array}$ & $\begin{array}{c}\mathrm{Zn}-\mathrm{S} \\
(\mathrm{ppm})\end{array}$ & $\begin{array}{c}\mathrm{Zr}-\mathrm{S} \\
(\mathrm{ppm})\end{array}$ \\
\hline$<0.05$ & $<4.6$ & $1,100.0$ & 3.5 & 15.0 & 22.0 & $<1.5$ & $<10$ & 11 & 130 & 5.9 & 8.3 & $<10$ & 6.2 & $<1.5$ & 2,800 & 21.0 & 22.0 & 1.60 & $<10$ & 27.0 \\
\hline$<0.05$ & 9.4 & 990.0 & 4.4 & 12.0 & 20.0 & $<1.5$ & $<10$ & $<10$ & 140 & $<2.2$ & 13.0 & II & 7.2 & $<1.5$ & 3,100 & 29.0 & 28.0 & 1.90 & $<10$ & 38.0 \\
\hline$<0.05$ & $<4.6$ & $1,100.0$ & 2.2 & 9.5 & 9.9 & $<1.5$ & $<10$ & $<10$ & 160 & 4.2 & 4.3 & $<10$ & 6.4 & $<1.5$ & 3,200 & 11.0 & 24.0 & 1.60 & $<10$ & 24.0 \\
\hline$<0.05$ & $<4.6$ & $1,300.0$ & $<1.0$ & $<1.0$ & 2.4 & $<1.5$ & 38 & $<10$ & 190 & $<4.0$ & $<1.5$ & $<10$ & 7.2 & 2.7 & 1,800 & 5.5 & 37.0 & 2.60 & $<10$ & 14.0 \\
\hline 0.10 & $<4.6$ & 480.0 & $<1.0$ & $<1.0$ & 2.0 & $<1.5$ & $<10$ & $<10$ & 140 & 2.5 & $<1.5$ & $<10$ & 3.9 & $<1.5$ & 2,600 & 1.8 & 12.0 & 0.73 & $<10$ & 5.0 \\
\hline$<0.05$ & $<4.6$ & 460.0 & 2.8 & $<1.0$ & 8.2 & $<1.5$ & $<10$ & $<10$ & 440 & 5.1 & 5.8 & $<10$ & 5.7 & $<1.5$ & 3,100 & 3.4 & 24.0 & 1.50 & $<10$ & 6.8 \\
\hline$<0.05$ & $<4.6$ & 610.0 & 4.1 & $<1.0$ & 9.8 & $<1.5$ & $<10$ & $<10$ & 440 & $<2.2$ & 4,3 & $<10$ & 4.8 & $<1.5$ & 3,200 & 2.3 & 26.0 & 2.00 & $<10$ & 8.6 \\
\hline$<0.05$ & $<4.6$ & 680.0 & 1.9 & $<1.0$ & 6.8 & $<1.5$ & 55 & $<10$ & 500 & 2.4 & 2.5 & $<10$ & 5.2 & $<1.5$ & 1,800 & 2.7 & 26.0 & 1.60 & 130 & 5.8 \\
\hline$<0.05$ & $<4.6$ & 730.0 & 2.1 & $<1.0$ & 8.3 & $<1.5$ & 46 & $<10$ & 560 & $<2.2$ & 2.6 & $<10$ & 5.3 & $<1.5$ & 1,900 & 1.9 & 28.0 & 1.80 & $<10$ & 8.0 \\
\hline$<0.05$ & $<4.6$ & 430.0 & 1.7 & $<1.0$ & 4.3 & $<1.5$ & 61 & $<10$ & 140 & $<2.2$ & 2.6 & $<10$ & 4.1 & 2.7 & 2,000 & 1.3 & 26.0 & 1.80 & $<10$ & 7.1 \\
\hline$<0.05$ & $<4.6$ & 610.0 & 2.0 & $<1.0$ & 6.3 & $<1.5$ & $<10$ & $<10$ & 550 & 2.8 & 2.5 & $<10$ & 4.7 & 5.7 & 2,200 & 2.0 & 23.0 & 1.60 & $<10$ & 9.6 \\
\hline$<0.05$ & $<4.6$ & 670.0 & $<1,0$ & $<1.0$ & 6.4 & $<1.5$ & 67 & $<10$ & 160 & 3.0 & $<1.5$ & $<10$ & 4.9 & $<1.5$ & 2,600 & 2.6 & 33.0 & 2.80 & $<10$ & 5.8 \\
\hline$<0.05$ & $<4.6$ & $1,600.0$ & 1.5 & 9.2 & 24.0 & $<1.5$ & 60 & $<10$ & 540 & $<2.2$ & 9.1 & $<10$ & 7.1 & $<1.5$ & 2,300 & 5.0 & 63.0 & 4.70 & $<10$ & 17.0 \\
\hline 0.10 & 7.1 & 650.0 & 31.0 & 62.0 & 72.0 & 2.4 & 41 & 38 & 820 & 13.0 & 170.0 & $<10$ & 7.5 & 2.8 & 1,200 & 22.0 & 32.0 & 2.00 & 260 & 58.0 \\
\hline$<0.05$ & $<4.6$ & 480.0 & 1.2 & $<1.0$ & 4.9 & $<1.5$ & 46 & $<10$ & 380 & $<2.2$ & 2.6 & $<10$ & 4.3 & $<1.5$ & 1,800 & 2.3 & 26.0 & 1.60 & $<10$ & 7.9 \\
\hline$<0.05$ & $<4.6$ & 520.0 & 1.2 & $<1.0$ & 4.2 & $<1.5$ & $<10$ & $<10$ & 160 & 3.4 & 1.7 & $<10$ & 5.0 & $<1.5$ & 2,200 & 2.0 & 23.0 & 1.10 & $<10$ & 5.9 \\
\hline$<0.05$ & $<4.6$ & 550.0 & $<1.0$ & $<1.0$ & 2.6 & $<1.5$ & $<10$ & $<10$ & 150 & 3.0 & $<1.5$ & $<10$ & 4.0 & $<1.5$ & 2,200 & 1.6 & 22.0 & 1.20 & $<10$ & 4.9 \\
\hline$<0.05$ & $<4.6$ & 510.0 & $<1.0$ & $<1.0$ & 3.0 & $<1.5$ & 29 & $<10$ & 120 & $<2.2$ & $<1.5$ & $<10$ & 3.5 & $<1.5$ & 2,100 & 1.2 & 19.0 & 1.20 & $<10$ & 5.8 \\
\hline$<0.05$ & $<4.6$ & 550.0 & $<1.0$ & $<1.0$ & 3.9 & $<1.5$ & 61 & $<10$ & 340 & $<2.2$ & $<1.5$ & $<10$ & 4.3 & 4.0 & 1800 & 1.5 & 21.0 & 1.40 & $<10$ & 5.4 \\
\hline$<0.05$ & $<4.6$ & 500.0 & 16 & $<1.0$ & 3.5 & $<1.5$ & 60 & $<10$ & 450 & $<2.2$ & 1.6 & $<10$ & 4.0 & $<1.5$ & 2,300 & 1.3 & 24.0 & 160 & $<10$ & 7.9 \\
\hline$<0.05$ & $<4.6$ & & 1.5 & $<1.0$ & 3.1 & $<1.5$ & $<10$ & $<10$ & 310 & $<2.2$ & 2.0 & $<10$ & .5 & $<1.5$ & 2100 & 2.9 & 330 & 70 & $<10$ & 6.3 \\
\hline$<0.05$ & $<4.6$ & & 1.5 & $<1.0$ & 2.2 & $<1.5$ & 54 & $<10$ & 96 & 25 & 2.2 & $<10$ & 4.1 & $<1.5$ & 1,900 & 1.5 & 220 & 0 & $<10$ & 5.3 \\
\hline 0.30 & $<4.6$ & & 1.8 & $<1.0$ & 3.3 & $<1.5$ & 35 & $<10$ & 130 & $<2.2$ & 3.4 & $<10$ & 3.6 & $<1.5$ & 2000 & 2.1 & 12.0 & 33 & $<10$ & 6.3 \\
\hline$<0.05$ & $<4.6$ & & $<1.0$ & $<1.0$ & 1.5 & $<1.5$ & $<10$ & $<10$ & 150 & $<2.2$ & $<1.5$ & $<$ & .7 & 5.4 & & 1.4 & & 1,60 & $<10$ & 5.5 \\
\hline$<0.05$ & $<4.6$ & & & $<1.0$ & 2.1 & $<1.5$ & $<10$ & $<10$ & 110 & 3.1 & $<1.5$ & $<10$ & 3.5 & $<1.5$ & & 1.3 & & 0 & & 4.6 \\
\hline$<0.05$ & $<4.6$ & 750.0 & 1. & $<1.0$ & 3.6 & $<1.5$ & 47 & $<10$ & 160 & $<2.2$ & 1.5 & $<10$ & 4.4 & & & 1.9 & & 0 & & 3.7 \\
\hline$<0.05$ & $<4.6$ & $1,100.0$ & 1. & $<1.0$ & 4.3 & $<1.5$ & 35 & $<10$ & 180 & 2.8 & 1.6 & $<10$ & $<1.0$ & & & 1.8 & & & & 6.2 \\
\hline$<0.05$ & $<4.6$ & 8.1 & $<1.0$ & & 2.7 & $<1.5$ & $<10$ & $<1$ & 22 & & 9.0 & $<10$ & & & & & & & & 11.0 \\
\hline$<0.05$ & $<4.6$ & 230.0 & $<1$ & 14 & 3.5 & $<1.5$ & $<10$ & $<1$ & 82 & & 9.1 & & & & & & & & & 28.0 \\
\hline 0. & $<4.6$ & 180.0 & & & 3.6 & 30 & 68 & $<10$ & 400 & 2 & 7.6 & $<10$ & & $<1.5$ & 7 & 70.0 & & & $<10$ & 350.0 \\
\hline 0. & 12.0 & $48 \mathrm{C}$ & & & 4 & & 63 & 17 & 470 & & .6 & & & $<$ & 6 & 110.0 & & & & 380.0 \\
\hline 0. & $<4.6$ & 52.0 & & & 3 & 2.3 & 58 & $<10$ & & 5.3 & .7 & $<10$ & & $<$ & 6 & 98 & & & $<10$ & 230.0 \\
\hline 0.4 & 30.0 & 200.0 & 2 & a. & 1.6 & 7.4 & 79 & 2 & 3 & 5.2 & 3.6 & $<$ & 1 & $<$ & 520 & 130 & 0 & & $<10$ & 620.0 \\
\hline 0. & $<4$. & & 1. & 13 & 11.0 & 1.5 & 48 & $<10$ & & 18.0 & 26.0 & $<$ & 6 & $<1.5$ & 急 & 43 & & & & 200.0 \\
\hline$<0.05$ & $<4$ & 6 & $<1.0$ & 10. & 3 & $<1.5$ & $<10$ & $<10$ & 1 & 0 & 14.0 & $<$ & & & 2,100 & & & & & \\
\hline 0.0 & $<4.6$ & 15.0 & 1.1 & 3 & 1. & 4.1 & 43 & 20 & 18 & 13 & 4.5 & $<$ & & .1 & 220 & 120 & 18.0 & & $<10$ & 310.0 \\
\hline$<0.05$ & $<4.6$ & 83.0 & $<1.0$ & 13 & . & & 33 & $<1$ & 1 & 37. & 37.0 & $<$ & & 8 & & & & & & 180.0 \\
\hline$<0.0$ & $<4.6$ & $<22.0$ & 1. & 14 & 11. & $<1.5$ & $<10$ & $<1$ & 1 & 23 & 34.0 & $<$ & & & & & & & 0 & 78.0 \\
\hline$<0$. & 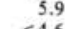 & 11 & 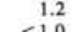 & 53.0 & 26 & 1.6 & - & $<10$ & 1 & & 120.0 & $<$ & & $<1.5$ & 2,0 & & & & & 120.0 \\
\hline $\begin{array}{l}<0.05 \\
<0.05\end{array}$ & $<4.6$ & 13 & $<1.0$ & 9 & 2 & $<1.5$ & $<10$ & 1 & 1 & & 12.0 & $<$ & & & & & & & & 3.0 \\
\hline $\begin{array}{r}<0.05 \\
0.20\end{array}$ & $\begin{array}{r}<4.6 \\
9.8\end{array}$ & $\begin{array}{r}16.0 \\
100.0\end{array}$ & $<1$. & 2. & 1.6 & $\begin{array}{r}<1.5 \\
8.9\end{array}$ & $\begin{array}{r}<10 \\
42\end{array}$ & $<10$ & $\begin{array}{l}100 \\
200\end{array}$ & 14. & $\begin{array}{r}8.9 \\
11.0\end{array}$ & $\begin{array}{r}<10 \\
19\end{array}$ & $\begin{array}{l}5.3 \\
2.9\end{array}$ & $\begin{array}{l}5.8 \\
2.4\end{array}$ & $\begin{array}{r}2,200 \\
440\end{array}$ & $\begin{array}{l}160 \\
440\end{array}$ & $\begin{array}{l}11.0 \\
13.0\end{array}$ & 4.20 & $\begin{array}{l}230 \\
120\end{array}$ & $\begin{array}{r}52.0 \\
660.0\end{array}$ \\
\hline$<0$. & $\begin{array}{r}3.0 \\
<4.6\end{array}$ & 11.0 & $<1.0$ & 7.9 & 2. & $\begin{array}{r}8.9 \\
<1.5\end{array}$ & $\begin{array}{r}42 \\
<10\end{array}$ & $<10$ & 64 & 18 & 12.0 & $<10$ & $<1.0$ & $<1.5$ & 1,3 & 18 & 7.7 & 1. & 250 & 16.0 \\
\hline$<0$. & $<4.6$ & 11.0 & $<1.0$ & 9.5 & 2. & $<1.5$ & $<1$ & $<10$ & 9 & is & 15.0 & $<$ & 5.1 & $<1.5$ & $i, 6$ & 33 & 7.8 & $i$. & 250 & 16.0 \\
\hline$<0$. & $<4.6$ & 13.0 & $<1$. & 7.1 & i. & $<1$ & $<10$ & $<10$ & 11 & 19 & 17 & $<$ & 5. & $<1$ & 2, & 32 & 9.8 & i. & $<10$ & 47.0 \\
\hline 0. & $\begin{array}{l}<4.6 \\
<4.6\end{array}$ & 90 & 1. & 21.0 & 22. & 1 & 92 & 10 & 4 & 5 & 99.0 & $<1$ & 6 & $<1.5$ & 1,3 & 72 & 47.0 & 6 & 360 & 370.0 \\
\hline$<0.0$ & 8.2 & 99.0 & 1 & 2.9 & $<1.5$ & 7 & $\begin{array}{l}92 \\
45\end{array}$ & 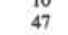 & 3 & 1 & 6.3 & 23 & 2.8 & $<1.5$ & 2 & 30 & 16.0 & 2 & 96 & $1,100.0$ \\
\hline 0.5 & 7.7 & $2,600.0$ & 2 . & 12. & 3.1 & 6.1 & 31 & 4 & 3 & 17 & 11.0 & 14 & 2.7 & 2.2 & 7 & 40 & 11.0 & 3. & 89 & 380.0 \\
\hline$<0$. & $<4.6$ & 14,0 & $<1.0$ & 11.0 & 2 & $\begin{array}{l}0.1 \\
<1.5\end{array}$ & $\begin{array}{l}31 \\
29\end{array}$ & $<10$ & 13 & 25 & 19.0 & $\begin{array}{l}14 \\
<10\end{array}$ & $<1.0$ & $<1.5$ & 2,0 & 42 & 8.4 & 1. & 270 & 31.0 \\
\hline$<0$. & $<4.6$ & 13 & $<1.0$ & 9.9 & 2 & $<1.5$ & $<10$ & $<10$ & 13 & II & 12.0 & $<$ & 4.9 & 3.2 & i, & 18 & 4.8 & 1 & 50 & 12.0 \\
\hline$<0$. & $<4.6$ & $<22.0$ & 1.3 & 21.0 & 15. & $<1.5$ & $<10$ & $<10$ & $1,1 \mathrm{c}$ & 4 & 68.0 & $<$ & 5.1 & $<1.5$ & 2,200 & 90 & 17.0 & 4 & 400 & 44.0 \\
\hline$<0.0$ & $<4.6$ & 88.0 & i. & 25 & 21 & $<1$ & 20 & 11 & 1,1 & 49 & 79.0 & $<$ & 4.6 & $<1.5$ & 1,400 & 1,00 & 18.0 & & 360 & 68.0 \\
\hline$<0.0$ & $<4.6$ & 76.0 & 1.1 & 26 & 15 . & $<1.5$ & $<10$ & 15 & 1,7 & 32 & 53.0 & $<10$ & 5.1 & 4.4 & 1,100 & 76 & i. & 3 & 40 & 68.0 \\
\hline 0.0 & $<4.6$ & 95.0 & 1.6 & 62.0 & 34.0 & $<1.5$ & $<10$ & $<10$ & 2,3 & 39 & 77.0 & 11 & 5.6 & $<1.5$ & 1,3 & 98 & 19.0 & 5 & 580 & 91.0 \\
\hline$<0$. & $<4.6$ & 81.0 & 1.1 & 22.0 & 16.0 & 4.0 & 38 & 15 & 3,4 & 42 & 81.0 & $<10$ & 4.9 & $<1$ & 7 & 78 & 21.0 & 4. & 420 & 100.0 \\
\hline$<0$. & $<4.6$ & 670.0 & 2. & 13 & 6.2 & 3.0 & $<10$ & $<10$ & 1,5 & 59 & 33.0 & $<1$ & 6.0 & $<1$ & 75 & 18 & 1 & 1. & 250 & 100.0 \\
\hline$<0.05$ & $<4,6$ & $<22.0$ & $<1.0$ & 15 & 6.3 & 2.8 & $<10$ & 10 & 3,7 & 20 & 37 & $<1$ & $<1.0$ & $<1$ & $46 x$ & 38 & 17.0 & 3 & 320 & 92.0 \\
\hline 0.40 & 16.0 & 120.0 & $<1.0$ & 12.0 & 12.0 & 14.0 & so & 61 & 1,100 & 26. & 56.0 & 43 & 2.0 & 2 & 190 & 220 & 35.0 & 3 & 430 & 170.0 \\
\hline 0.2 & 20.0 & 40.0 & $<1.0$ & $<1.0$ & $<1.5$ & 17.0 & 16 & 100 & 130 & 44.0 & 5.5 & $<10$ & $<1.0$ & $<1$ & 24 & 13 & 3.0 & 0. & 55 & 130.0 \\
\hline 0.1 & $<10,0$ & $>3,200.0$ & 1.4 & $<1.0$ & $<1.5$ & 9.1 & 44 & 28 & 1,200 & 9.6 & 17.0 & 12 & $<1.0$ & $<1$ & 0 & 23 & 9.7 & 1. & 170 & 200.0 \\
\hline 0.50 & 23.0 & 340.0 & 2.5 & 4.2 & 5.3 & 26. & 51 & 69 & 430 & 5.8 & 12.0 & 32 & 3.5 & 3.3 & 73 & 34 & 30.0 & 4.00 & 33 & 410.0 \\
\hline 0.40 & 27.0 & $1,500.0$ & 1.7 & $<1.0$ & 2.6 & 25.0 & 40 & 110 & 490 & 9.2 & 11.0 & 43 & 2.2 & 1.6 & 120 & 18.0 & 16.0 & 1.90 & 28 & 320.0 \\
\hline
\end{tabular}




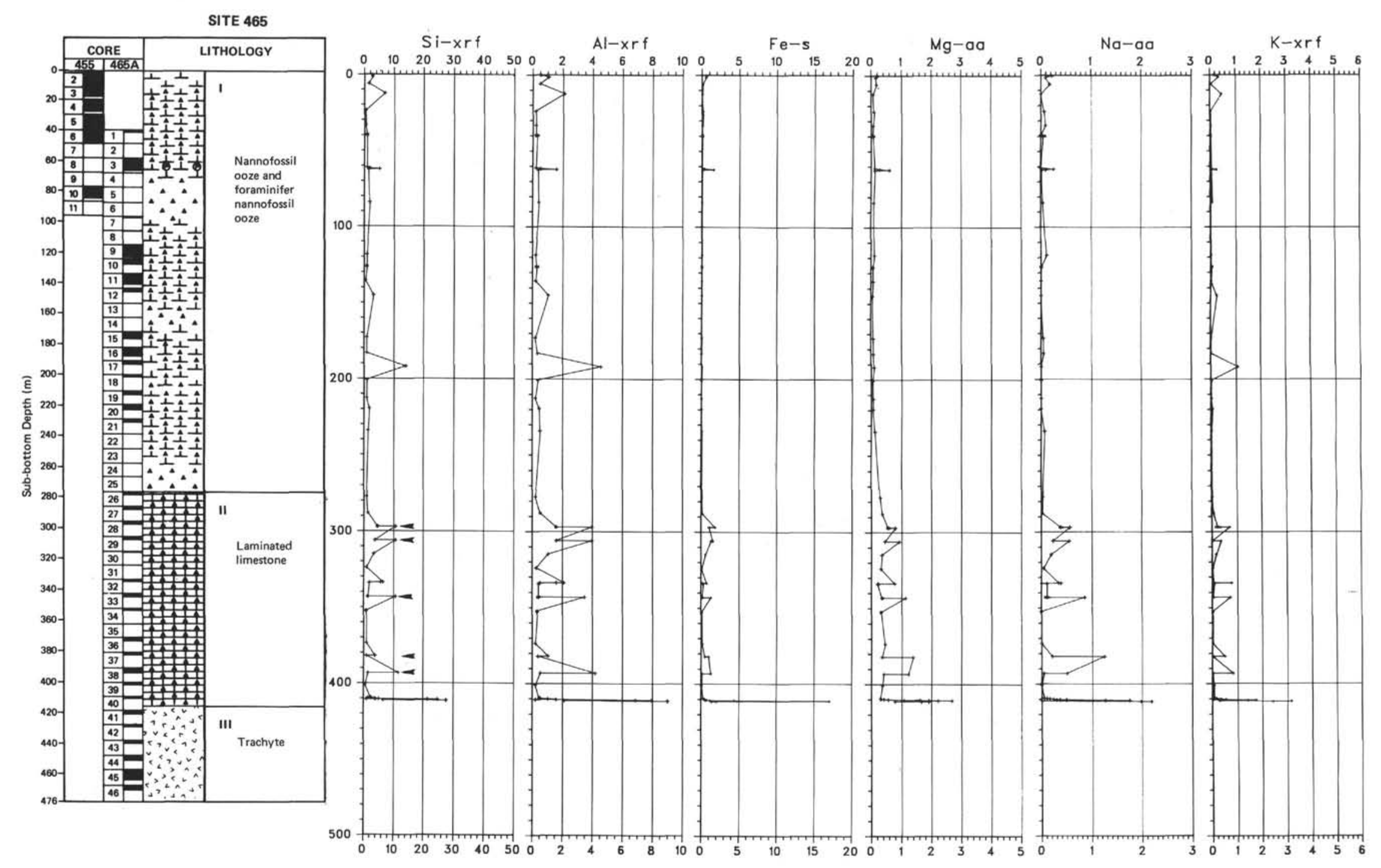




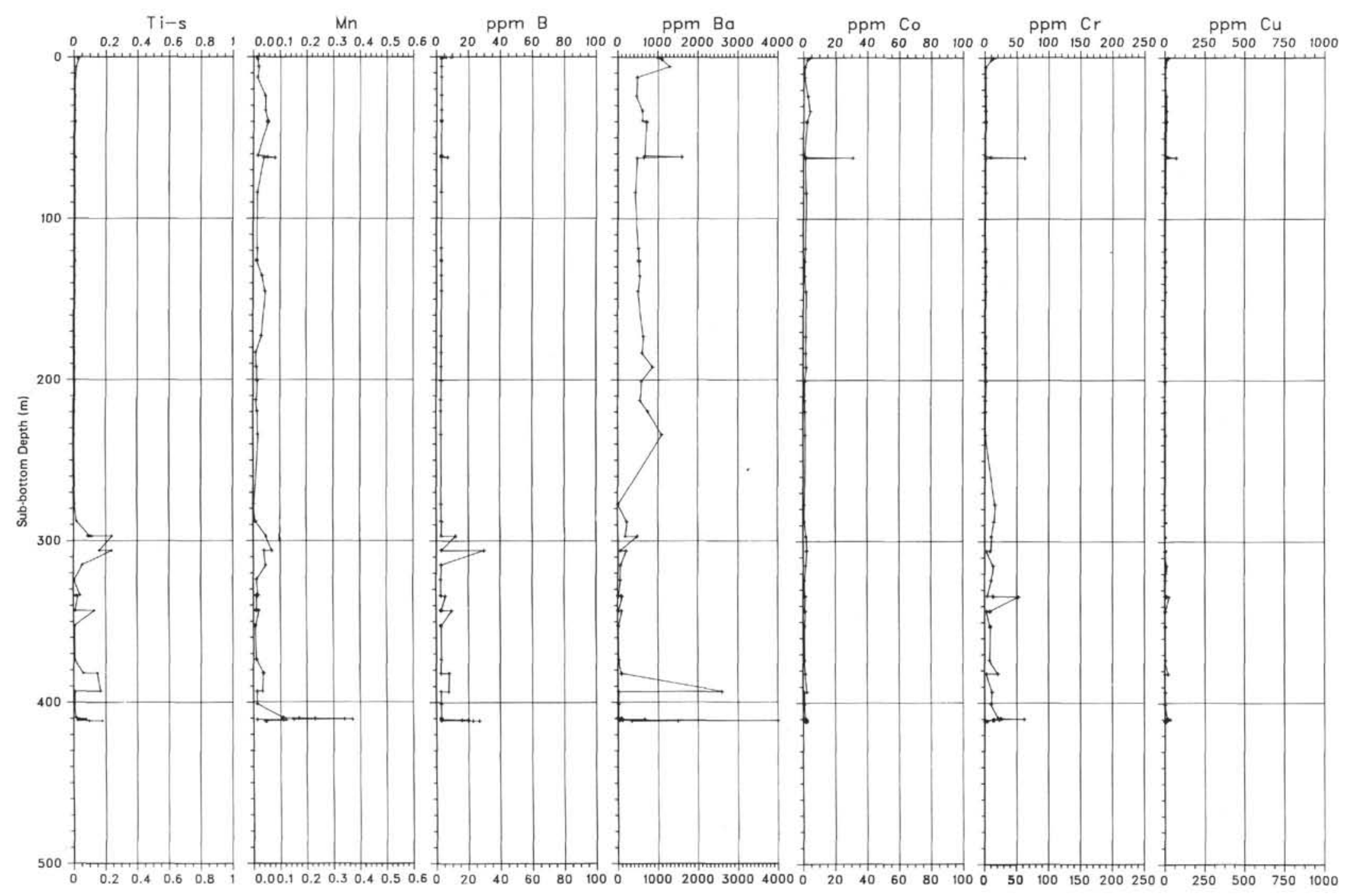

Figure 5. Lithologic summary and plots of element concentrations in samples from Holes 465 and $465 \mathrm{~A}$. Element concentrations are in percent (unlabeled) or parts per million (labeled ppm) dry weight. Analyses were by X-ray fluorescence (xrf), semiquantitative optical emission spectroscopy (s), or atomic absorption spectrophotometry (aa). Duplicate analyses are indicated by two points connected by a horizontal bar at the same depth. The thickness of the black interval beside each core number in the column labeled "core" indicates the proportion of the cored interval that was recovered. Arrows by concentrations of $\mathrm{Si}$ in five samples from Unit II indicate samples of gray limestone that are interbedded with olive laminated limestone. 


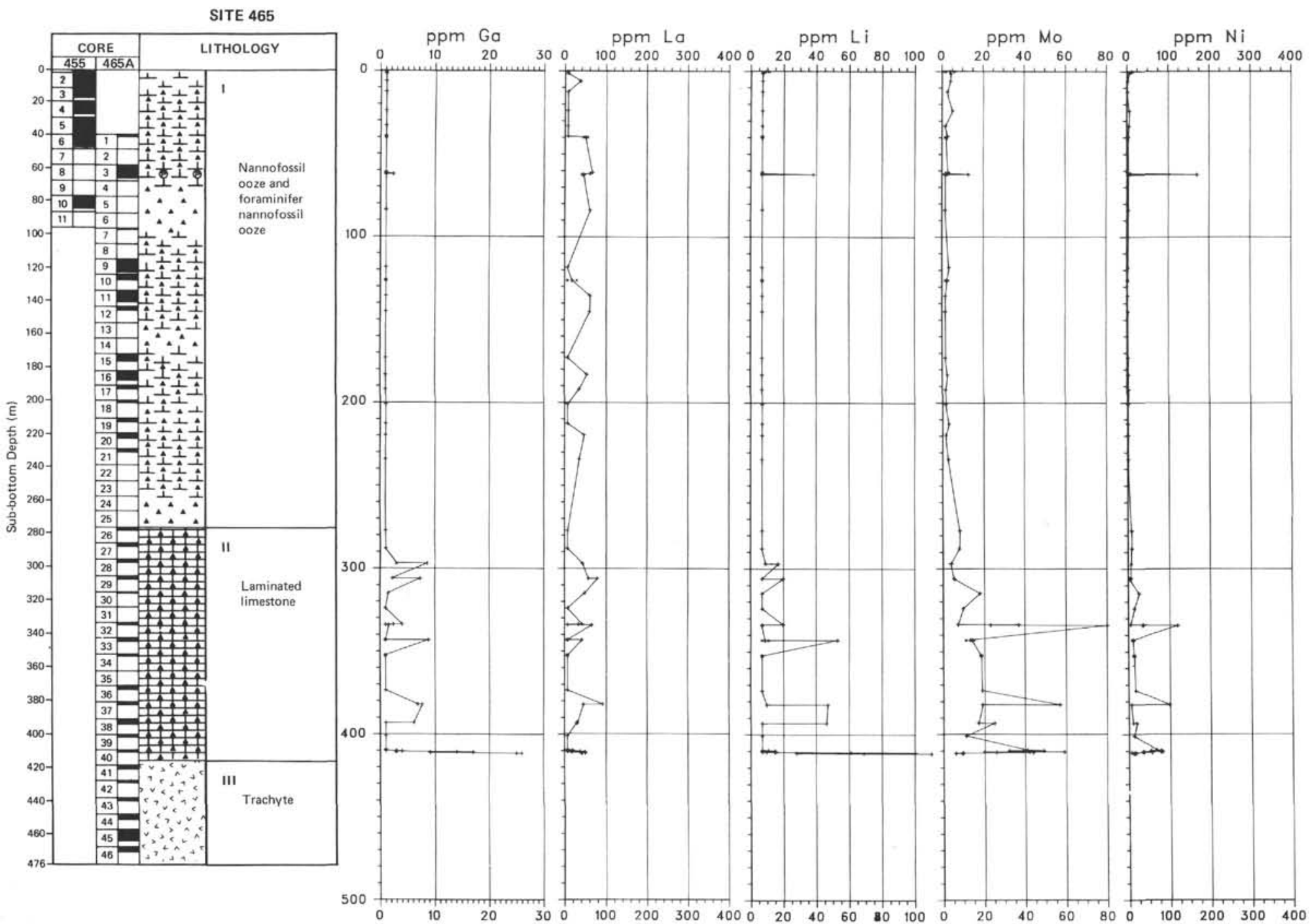

Figure 5. (Continued). 


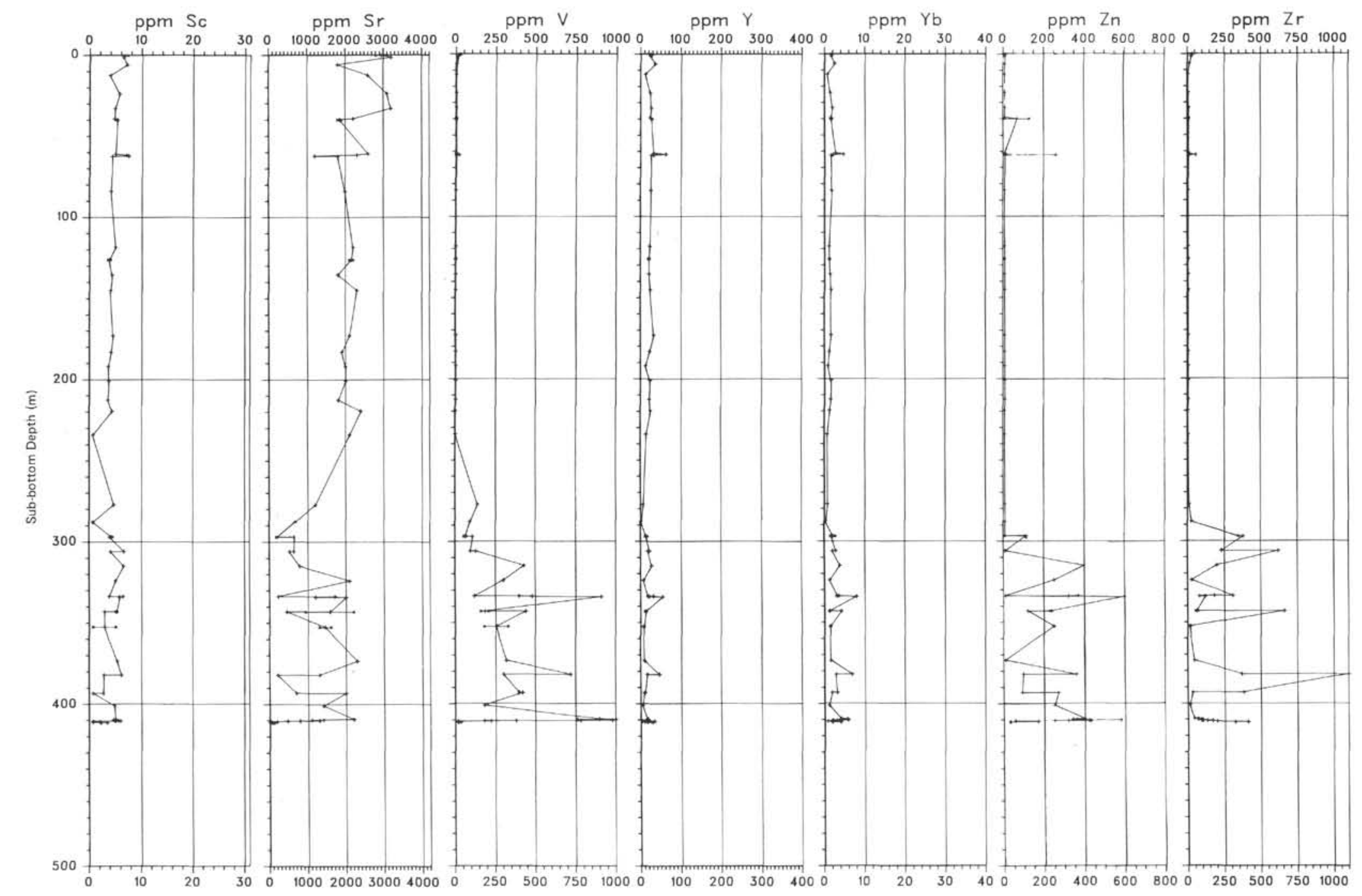

Figure 5. (Continued). 


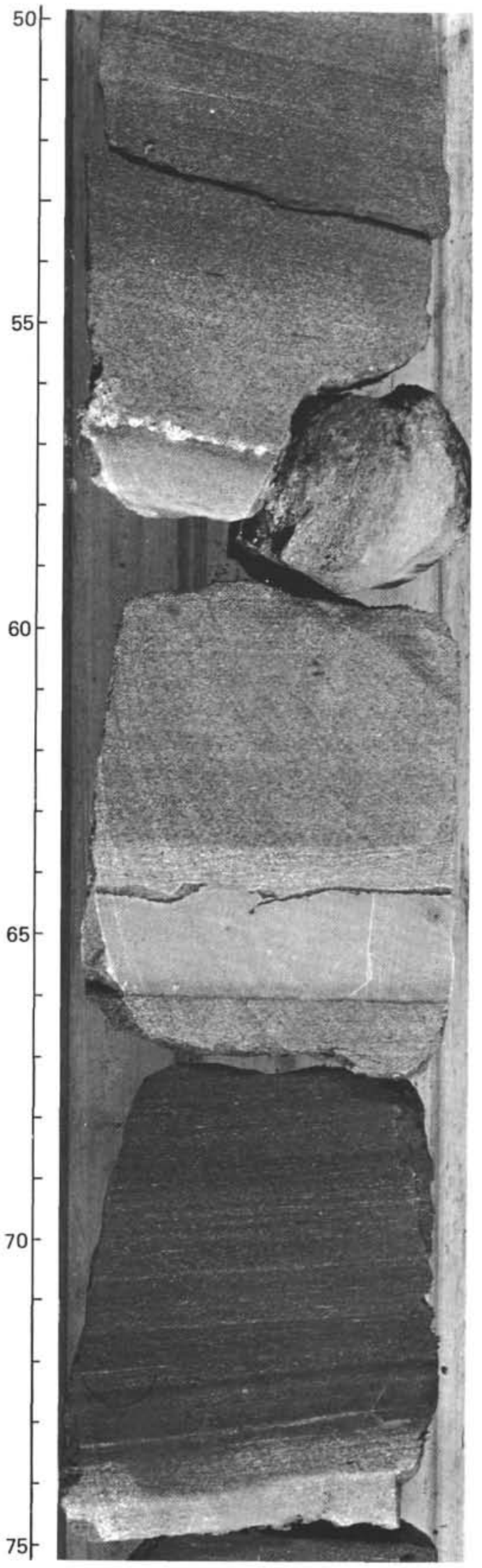

Figure 6. Thin bed of gray massive limestone in olive laminated limestone from Lithologic Unit II, Hole 465A, Core 36, Section 2, 50 to $75 \mathrm{~cm}$. Subdivisions on scale are in millimeters.
Table 6. Summary statistics for total element concentrations in 24 samples of olive laminated limestone and five samples of gray massive limestone from Lithologic Unit II, Hole 465A.

\begin{tabular}{|c|c|c|c|c|c|c|}
\hline \multirow[b]{2}{*}{ Element } & \multicolumn{3}{|c|}{ Olive Laminated Limestone } & \multicolumn{3}{|c|}{ Gray Massive Limestone } \\
\hline & $\begin{array}{c}\text { Observed } \\
\text { Range }\end{array}$ & $\begin{array}{l}\text { Arithmetic } \\
\text { Mean }\end{array}$ & $\begin{array}{c}\text { Standard } \\
\text { Deviation }\end{array}$ & $\begin{array}{l}\text { Observed } \\
\text { Range }\end{array}$ & $\begin{array}{l}\text { Arithmetic } \\
\text { Mean }\end{array}$ & $\begin{array}{l}\text { Standard } \\
\text { Deviation }\end{array}$ \\
\hline Si $(\%)$ & $0.47-6.5$ & 2.6 & 1.7 & $0.94-12$ & 9.0 & 4.5 \\
\hline $\mathrm{Al}$ & $0.21-2.1$ & 0.83 & 0.59 & $0.37-4.2$ & 3.2 & 1.6 \\
\hline $\mathrm{Fe}$ & $0.046-1.6$ & 0.34 & 0.34 & $1.0-1.3$ & 1.2 & 0.14 \\
\hline $\mathrm{Mg}_{\mathrm{g}}$ & $0.24-1.9$ & 0.50 & 0.40 & $0.80-1.4$ & 1.1 & 0.23 \\
\hline $\mathrm{Na}$ & $0.0001-0.42$ & 0.15 & 0.14 & $0.50-1.2$ & 0.75 & 0.31 \\
\hline $\mathrm{K}$ & $<0.017-0.78$ & 0.15 & 0.20 & $<0.017-0.83$ & 0.53 & 0.33 \\
\hline $\mathrm{Ti}$ & $<0.013-0.16$ & 0.033 & 0.038 & $0.13-0.24$ & 0.19 & 0.051 \\
\hline $\mathrm{Ba}(\mathrm{ppm})$ & $8-230$ & 56 & 58 & $99-2600$ & 700 & 110 \\
\hline Co & $<0.7-1.9$ & 1.0 & 0.38 & $1.3-2.5$ & 1.8 & 0.60 \\
\hline $\mathrm{Cr}$ & $3.6-62$ & 18 & 15 & $2.7-12$ & 5.1 & 4.6 \\
\hline $\mathrm{Cu}$ & $1.6-34$ & 9.2 & 9.1 & $<1.0-3.1$ & 1.9 & 0.90 \\
\hline $\mathrm{La}$ & $<7.0-92$ & 25 & 25 & $31-79$ & 49 & 21 \\
\hline $\mathrm{Li}$ & $<7.0-20$ & 8.9 & 3.4 & $17-53$ & 37 & 17 \\
\hline $\mathrm{Mn}$ & $22-3700$ & 700 & 1100 & $200-470$ & 350 & 99 \\
\hline Mo & $<1.5-80$ & 24 & 19 & $5.2-19$ & 14 & 6.1 \\
\hline $\mathrm{Ni}$ & $4.5-120$ & 36 & 34 & $3.6-11$ & 8.0 & 3.7 \\
\hline Sc & $<0.70-6.7$ & 4.5 & 1.9 & $2.7-4.2$ & 3.3 & 0.66 \\
\hline $\mathrm{Sr}$ & $190-2300$ & 1300 & 600 & $210-700$ & 500 & 190 \\
\hline v & $55-1000$ & 430 & 310 & $110-440$ & 280 & 150 \\
\hline$Y$ & $1.0-55$ & 17 & 13 & $11-18$ & 14 & 2.7 \\
\hline $\mathrm{Y}_{\mathrm{b}}$ & $0.30-8.0$ & 3.0 & 2.0 & $1.8-4.2$ & 2.8 & 0.97 \\
\hline $\mathrm{Zr}$ & $11-370$ & 110 & 110 & $380-1100$ & 630 & 290 \\
\hline
\end{tabular}




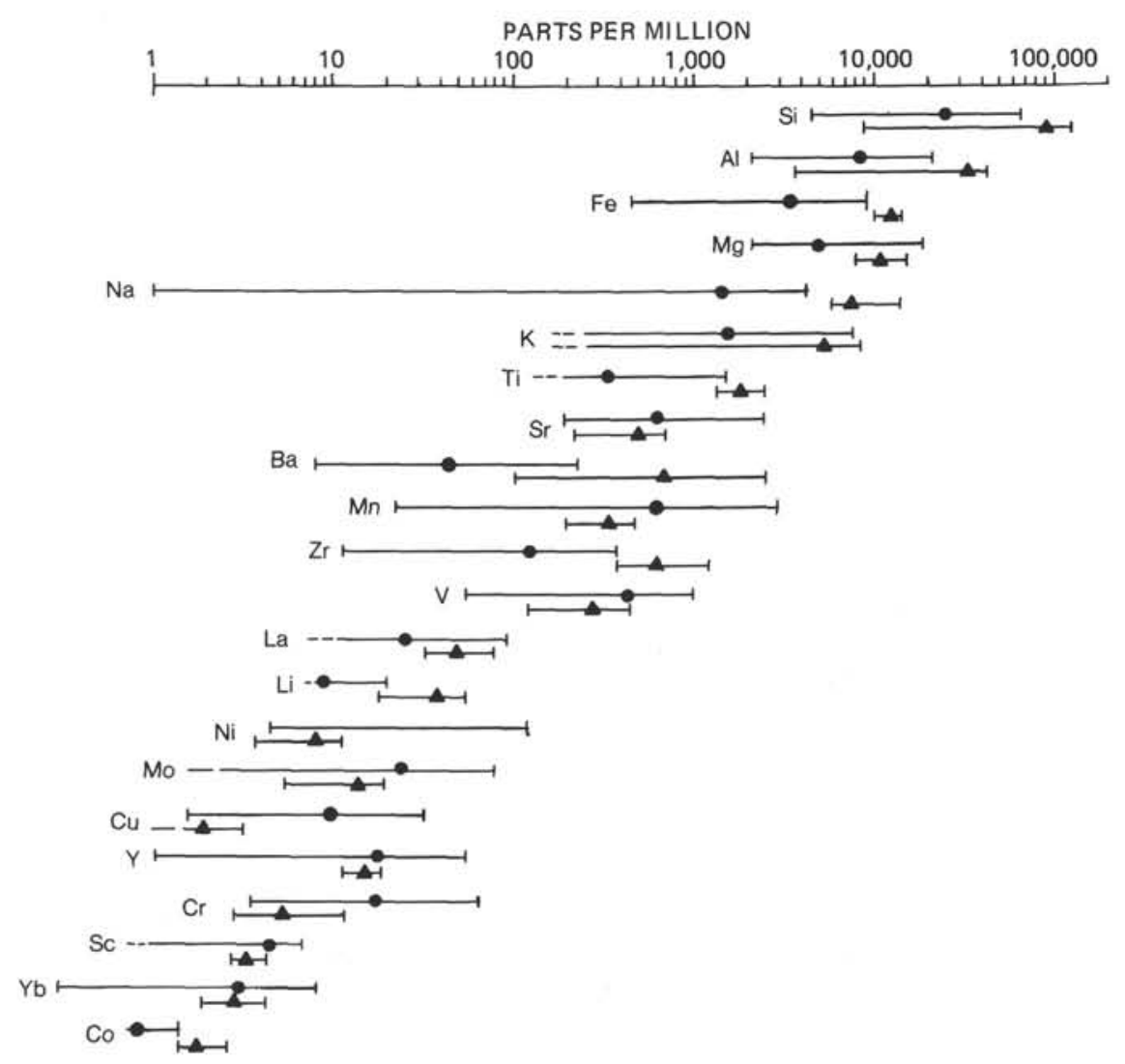

Figure 7. Comparison of element concentrations in 25 samples of olive laminated limestone (dots) and five samples of gray massive limestone (triangles) from Lithologic Unit II, Hole 465A. Dots and triangles represent the mean concentration for each element (Table 6). Bars indicate observed ranges of element concentrations (Table 6). A dash at the lower end of a bar indicates that the lowest concentration of the element was below the limit of detection. 
Table 7. Chemical analyses of samples from Hole 466.

\begin{tabular}{|c|c|c|c|c|c|c|c|c|c|c|c|c|c|c|c|}
\hline Sample & $\begin{array}{l}\text { Site-Core-Section, } \\
\text { Interval }(\mathrm{cm})\end{array}$ & $\begin{array}{l}\text { Sub-bottom } \\
\text { Depth } \\
\text { (m) }\end{array}$ & $\begin{array}{c}\mathrm{SiO}_{2}-\mathrm{S} \\
(\%)\end{array}$ & $\begin{array}{c}\mathrm{SiO}_{2} \text {-xrf } \\
(\%)\end{array}$ & $\underset{(\%)}{\mathrm{Al}_{2} \mathrm{O}_{3}-\mathrm{S}}$ & $\begin{array}{l}\mathrm{Al}_{2} \mathrm{O}_{3}-\mathrm{xrf} \\
(\%)\end{array}$ & $\begin{array}{c}\mathrm{Fe}_{2} \mathrm{O}_{3}-\mathrm{S} \\
(\%)\end{array}$ & $\underset{(\%)}{\mathrm{Fe}_{2} \mathrm{O}_{3} \text {-xrf }}$ & $\underset{(\%)}{\mathrm{MgO}-\mathrm{swc}}$ & $\underset{(\%)}{\mathrm{CaO}-\mathrm{S}}$ & $\underset{(\%)}{\mathrm{CaO}-\mathrm{xrf}}$ & $\begin{array}{l}\mathrm{Na}_{2} \mathrm{O}-\mathrm{swc} \\
(\%)\end{array}$ & $\underset{(\%)}{\mathrm{K}_{2} \mathrm{O}-\mathrm{S}}$ & $\begin{array}{c}\mathrm{K}_{2} \mathrm{O}-\mathrm{xrf} \\
(\%)\end{array}$ & $\underset{(\%)}{\mathrm{TiO}_{2}-\mathrm{S}}$ \\
\hline 60011130 & $466-1-1,130$ & 1.32 & 5.35 & 13.0 & 1.57 & 3.0 & 0.872 & 0.92 & 0.508 & 28 & 52 & 0.3756 & 0.78 & 0.75 & 0.072 \\
\hline 60014020 & $466-1-4,20$ & 4.70 & 1.33 & 6.5 & 0.30 & 2.0 & 0.372 & 0.58 & 0.168 & 35 & 56 & 0.0456 & 0.39 & 0.64 & 0.012 \\
\hline 60022036 & $466-2-2,36$ & 9.86 & 1.48 & 5.0 & 0.25 & 2.0 & 0.372 & 0.09 & 0.198 & 31 & 61 & 0.2756 & 0.35 & 0.20 & $<0.010$ \\
\hline 60026032 & $466-2-6,32$ & 15.82 & 11.98 & 18.0 & 3.59 & 4.0 & 1.573 & 1.30 & 1.033 & 36 & 46 & 0.4758 & 1.16 & 1.20 & 0.210 \\
\hline 60031137 & $466-3-1,137$ & 18.87 & 6.85 & 5.2 & 1.89 & 1.0 & 0.987 & 0.08 & 0.506 & $>45$ & 62 & 0.3257 & 0.84 & 0.30 & 0.093 \\
\hline 60031138 & $466-3-1,137$ & 18.87 & 4.49 & 10.0 & 1.42 & 3.0 & 0.886 & 0.77 & 0.524 & 31 & 55 & 0.2507 & 0.78 & 0.66 & 0.057 \\
\hline 60033023 & $466-3-3,23$ & 20.73 & 1.67 & 5.0 & 0.30 & 1.0 & 0.458 & 0.20 & 0.267 & 34 & 62 & 0.2006 & 0.36 & 0.30 & $<0.010$ \\
\hline 60042008 & $466-4-2,8$ & 28.58 & 1.84 & 6.4 & 0.45 & 2.0 & 0.572 & 0.30 & 0.321 & 27 & 59 & 0.1855 & 0.48 & 0.41 & 0.015 \\
\hline 60051130 & $466-5-1,130$ & 37.80 & 0.92 & 4.0 & 0.23 & 1.0 & 0.343 & $<0.05$ & 0.178 & 29 & 63 & 0.1556 & 0.35 & 0.30 & $<0.010$ \\
\hline 60051131 & $466-5-1,130$ & 37.80 & 0.66 & 4.0 & 0.21 & 1.0 & 0.315 & $<0.05$ & 0.156 & 31 & 63 & 0.0257 & 0.33 & 0.20 & $<0.010$ \\
\hline 60061073 & $466-6-1,73$ & 46.73 & 2.57 & 10.0 & 0.87 & 3.0 & 0.686 & 0.79 & 0.376 & 32 & 55 & 0.5257 & 0.55 & 0.62 & 0.035 \\
\hline 60064073 & $466-6-4,73$ & 51.23 & 0.96 & 4.0 & 0.28 & 1.0 & 0.386 & 0.06 & 0.239 & 29 & 62 & 0.0505 & 0.39 & 0.30 & $<0.010$ \\
\hline 60072040 & $466-7-2,40$ & 57.40 & 1.37 & 4.0 & 0.32 & 1.0 & 0.443 & 0.09 & 0.216 & 35 & 62 & 0.1257 & 0.41 & 0.30 & $<0.010$ \\
\hline 60072041 & $466-7-2,40$ & 57.40 & 0.92 & 5.0 & 0.26 & 2.0 & 0.429 & 0.20 & 0.213 & 27 & 60. & 0.1758 & 0.42 & 0.30 & $<0.010$ \\
\hline 60076040 & $466-7-6,40$ & 63.40 & 0.39 & 2.0 & 0.09 & 0.7 & 0.200 & $<0.05$ & 0.106 & 41 & 65 & 0.0001 & 0.24 & $<0.03$ & $<0.010$ \\
\hline 60082130 & $466-8-2,130$ & 67.80 & 4.71 & 7.2 & 2.27 & 2.0 & 0.886 & 0.55 & 0.378 & $>45$ & 57 & 0.1456 & 0.70 & 0.64 & 0.098 \\
\hline 60082131 & $466-8-2,130$ & 67.80 & 4.28 & 27.0 & 1.62 & 8.4 & 0.844 & 4.20 & 0.440 & 39 & 27 & 0.1555 & 0.67 & 2.60 & 0.065 \\
\hline 60091008 & $466-9-1,8$ & 74.58 & 0.73 & 4.0 & 0.21 & 1.0 & 0.415 & 0.10 & 0.222 & 32 & 62 & 0.0679 & 0.33 & 0.20 & 0.014 \\
\hline 60091014 & $466-9-1,14$ & 74.64 & 15.83 & 2.0 & 4.72 & 0.6 & 3.574 & $<0.05$ & 0.856 & 17 & 65 & 1.3257 & 3.01 & 0.06 & 0.375 \\
\hline 60091024 & $466-9-1,24$ & 74.74 & 4.06 & 6.2 & 0.55 & 1.0 & 0.600 & 0.20 & 0.207 & 42 & 61 & 0.0001 & 0.42 & 0.40 & 0.041 \\
\hline 60092022 & $466-9 \cdot 2,22$ & 76.22 & 1.11 & 4.0 & 0.47 & 1.0 & 0.543 & 0.08 & 0.194 & 38 & 63 & 0.0001 & 0.39 & 0.20 & 0.024 \\
\hline 60111094 & $466-11-1,94$ & 88.94 & 0.34 & 7.1 & $<0.06$ & 2.0 & 0.087 & 0.40 & 0.129 & $>45$ & 59 & 0.0001 & 0.20 & 0.45 & $<0.010$ \\
\hline 60121054 & $466-12-1,54$ & 94.04 & 0.28 & 2.0 & $<0.06$ & 0.7 & 0.063 & $<0.05$ & 0.207 & 38 & 64 & 0.0001 & 0.20 & 0.09 & $<0.010$ \\
\hline 60133015 & $466-13-3,15$ & 106.15 & 0.32 & 2.0 & $<0.06$ & $<0.5$ & 0.079 & $<0.05$ & 0.121 & 32 & 64 & 0.0001 & 0.19 & 0.08 & $<0.010$ \\
\hline 60133016 & $466-13-3,15$ & 106.15 & 0.36 & 2.0 & $<0.06$ & 0.6 & 0.071 & $<0.05$ & 0.134 & 32 & 65 & 0.0001 & 0.19 & 0.04 & $<0.010$ \\
\hline 60141062 & $466-14-1,62$ & 113.12 & 4.06 & 8.7 & $<0.06$ & 0.9 & 0.109 & $<0.05$ & 0.097 & $>45$ & 61 & 0.0001 & 0.20 & 0.06 & $<0.010$ \\
\hline 60152015 & $466-15-2,15$ & 123.65 & 0.13 & 1.0 & $<0.06$ & $<0.5$ & 0.026 & $<0.05$ & 0.173 & 34 & 65 & 0.0180 & $<0.08$ & 0.20 & $<0.010$ \\
\hline 60161060 & $466-16-1,60$ & 132.10 & 0.47 & 3.0 & 0.09 & 0.7 & 0.172 & $<0.05$ & 0.122 & $>45$ & 64 & 0.0001 & 0.24 & 0.09 & $<0.010$ \\
\hline 60171084 & $466-17-1,84$ & 141.84 & 0.47 & 3.0 & $<0.06$ & 0.7 & 0.200 & 0.06 & 0.181 & 29 & 64 & 0.0104 & 0.30 & 0.20 & $<0.010$ \\
\hline 60291071 & $466-29-1,71$ & 255.71 & 6.42 & 8.6 & 1.51 & 2.0 & 0.701 & 0.20 & 0.319 & 41 & 49 & 0.0480 & 0.42 & 0.30 & 0.140 \\
\hline 60301011 & $466-30-1,11$ & 264.61 & 1.65 & 4.0 & 0.60 & 1.0 & 0.529 & 0.08 & 0.668 & 41 & 63 & 0.0376 & 0.19 & 0.10 & 0.093 \\
\hline 60341049 & $466-34-1,49$ & 293.49 & 5.13 & - & 0.70 & - & 0.400 & - & $0.34 \mathrm{I}$ & 42 & - & 0.0001 & 0.22 & - & 0.083 \\
\hline 60351026 & $466-35-1,26$ & 302.76 & 4.06 & 6.4 & 0.98 & 1.0 & 0.615 & 0.20 & 0.262 & 41 & 57 & 0.0003 & 0.40 & 0.30 & 0.056 \\
\hline
\end{tabular}

Note: Analyses were by $\mathrm{X}$-ray fluorescence (xrf), semiquantitative optical emission spectroscopy (S), and atomic absorption (aa); analytical values for Mg and Na by atomic absorption were corrected for interstitial sea water (swc; see text for method of correction). Dashes indicate no analysis. 
Table 7. (Continued).

\begin{tabular}{|c|c|c|c|c|c|c|c|c|c|c|c|c|c|c|c|c|c|c|c|c|}
\hline $\begin{array}{c}\mathrm{TiO}_{2} \text {-xrf } \\
(\%)\end{array}$ & $\begin{array}{c}\text { B-S } \\
\text { (ppm) }\end{array}$ & $\begin{array}{c}\mathrm{Ba}-\mathrm{S} \\
(\mathrm{ppm})\end{array}$ & $\begin{array}{l}\text { Co-S } \\
(\mathrm{ppm})\end{array}$ & $\begin{array}{l}\mathrm{Cr}-\mathrm{S} \\
(\mathrm{ppm})\end{array}$ & $\begin{array}{l}\mathrm{Cu}-\mathrm{S} \\
(\mathrm{ppm})\end{array}$ & $\begin{array}{l}\text { Ga-S } \\
(\mathrm{ppm})\end{array}$ & $\begin{array}{l}\text { La-S } \\
(\mathrm{ppm})\end{array}$ & $\begin{array}{l}\mathrm{Li}-\mathrm{aa} \\
(\mathrm{ppm})\end{array}$ & $\begin{array}{l}\mathrm{Mn}-\mathrm{S} \\
(\mathrm{ppm})\end{array}$ & $\begin{array}{l}\text { Mo-S } \\
(\mathrm{ppm})\end{array}$ & $\begin{array}{c}\mathrm{Ni}-\mathrm{S} \\
(\mathrm{ppm})\end{array}$ & $\begin{array}{l}\text { Rb-aa } \\
\text { (ppm) }\end{array}$ & $\underset{(\mathrm{ppm})}{\mathrm{Sc}-\mathrm{S}}$ & $\begin{array}{l}\text { Sn-S } \\
(\mathrm{ppm})\end{array}$ & $\begin{array}{l}\text { Sr-S } \\
(\mathrm{ppm})\end{array}$ & $\begin{array}{l}\text { V-S } \\
\text { (ppm) }\end{array}$ & $\begin{array}{c}\mathrm{Y}-\mathrm{S} \\
(\mathrm{ppm})\end{array}$ & $\begin{array}{l}\text { Yb-S } \\
\text { (ppm) }\end{array}$ & $\begin{array}{l}\mathrm{Zn}-\mathrm{S} \\
(\mathrm{ppm})\end{array}$ & $\underset{(\mathrm{ppm})}{\mathrm{Zr}-\mathrm{S}}$ \\
\hline 0.10 & 6.4 & 1,500 & 4.6 & 15.0 & 30.0 & 2.0 & 37 & 11 & 340 & 2.7 & 7.4 & $<10$ & 6.3 & $<1.5$ & 2,000 & 16.0 & 30 & 2.20 & $<10$ & 44.0 \\
\hline$<0.05$ & $<4.6$ & 1,100 & 2.7 & 4.1 & 13.0 & $<1.5$ & $<10$ & $<10$ & 600 & 4.1 & 3.5 & $<10$ & 4.8 & $<1.5$ & 4,200 & 4.9 & 22 & 1.50 & $<10$ & 15.0 \\
\hline$<0.05$ & $<4.6$ & 550 & 5.5 & 2.6 & 22.0 & $<1.5$ & $<10$ & $<10$ & 830 & 3.0 & 5.3 & 10 & 4.9 & $<1.5$ & 3,100 & 6.4 & 14 & 0.84 & $<10$ & 18.0 \\
\hline 0.20 & 27.0 & 1,600 & 9.3 & 23.0 & 22.0 & 4.9 & 42 & $<10$ & 390 & 2.9 & 25.0 & 26 & 11.0 & $<1.5$ & 2,100 & 42.0 & 31 & 2.60 & $<10$ & 89.0 \\
\hline$<0.05$ & 14.0 & 1,600 & 9.4 & 16.0 & 19.0 & 2.9 & $<10$ & 11 & 420 & $<2.2$ & 17.0 & 15 & 8.6 & 5.1 & 3,900 & 32.0 & 37 & 2.70 & $<10$ & 69.0 \\
\hline 0.08 & 6.3 & 1,400 & 7.3 & 65.0 & 22.0 & 1.8 & 40 & 12 & 390 & 3.8 & 16.0 & 15 & 7.5 & $<1.5$ & 2,200 & 21.0 & 25 & 1.80 & $<10$ & 39.0 \\
\hline$<0.05$ & $<4.6$ & 1,000 & 2.3 & 5.1 & 15.0 & $<1.5$ & $<10$ & $<10$ & 470 & 3.3 & 4.1 & $<10$ & 4.6 & $<1.5$ & 3,100 & 5.6 & 20 & 1.30 & $<10$ & 15.0 \\
\hline$<0.05$ & $<4.6$ & 1,000 & 3.1 & 6.4 & 17.0 & $<1.5$ & $<10$ & $<10$ & 410 & 2.8 & 3.3 & 10 & 4.4 & $<1.5$ & 3,300 & 11.0 & 22 & 1.50 & $<10$ & 17.0 \\
\hline$<0.05$ & $<4.6$ & 950 & 2.2 & 20.0 & 11.0 & $<1.5$ & $<10$ & $<10$ & 520 & 3.6 & 8.3 & 10 & $<1.0$ & 3.1 & 3,700 & 6.3 & 24 & 1.60 & $<10$ & 15.0 \\
\hline$<0.05$ & $<4.6$ & 870 & 1.6 & 93.0 & 6.9 & $<1.5$ & $<10$ & $<10$ & 550 & 2.9 & 2.6 & $<10$ & 4.6 & $<1.5$ & 2,800 & 4.0 & 20 & 1.10 & $<10$ & 10.0 \\
\hline 0.08 & $<4.6$ & 1,700 & 7.2 & 10.0 & 10.0 & 1.6 & 41 & $<10$ & 690 & $<2.2$ & 12.0 & 14 & 5.4 & $<1.5$ & 3,400 & 9.6 & 31 & 1.90 & $<10$ & 26.0 \\
\hline$<0.05$ & $<4.6$ & 1,200 & 2.8 & 6.7 & 8.0 & $<1.5$ & 37 & $<10$ & 900 & 2.6 & 6.7 & $<10$ & 4.3 & $<1.5$ & 2,500 & 5.4 & 24 & 1.40 & $<10$ & 16.0 \\
\hline$<0.05$ & $<4.6$ & 1,100 & 3.9 & 5.4 & 10.0 & $<1.5$ & $<10$ & $<10$ & 850 & 3.4 & 6.4 & $<10$ & 5.3 & $<1.5$ & 3,300 & 6.2 & 19 & 1.20 & $<10$ & 13.0 \\
\hline$<0.05$ & $<4.6$ & 1,000 & 4.3 & 8.9 & 11.0 & $<1.5$ & $<10$ & $<10$ & 540 & 3.0 & 4.9 & 10 & 4.3 & $<1.5$ & 3,200 & 5.6 & 22 & 1.40 & $<10$ & 13.0 \\
\hline$<0.05$ & $<4.6$ & 910 & 20.0 & 59.0 & 12.0 & $<1.5$ & $<10$ & $<10$ & 880 & $<2.2$ & 7.6 & $<10$ & 6.3 & $<1.5$ & 4,200 & 3.1 & 43 & 3.10 & $<10$ & 14.0 \\
\hline 0.06 & 13.0 & 3,000 & 47.0 & 13.0 & 32.0 & $<1.5$ & 210 & $<10$ & 5,700 & 10.0 & 91.0 & 14 & 17.0 & $<1.5$ & 3,500 & 30.0 & 250 & 16.00 & $<10$ & 120.0 \\
\hline 0.66 & 11.0 & 2,900 & 43.0 & 9.9 & 30.0 & $<1.5$ & 200 & $<10$ & 5,300 & 8.4 & 82.0 & 10 & 15.0 & $<1.5$ & 3,200 & 24.0 & 240 & 15.00 & $<10$ & 100.0 \\
\hline$<0.05$ & $<4.6$ & 1,100 & 5.4 & 9.2 & 18.0 & $<1.5$ & $<10$ & $<10$ & 990 & 3.5 & 17.0 & $<10$ & 5.5 & $<1.5$ & 1,900 & 5.3 & 43 & 2.90 & $<10$ & 20.0 \\
\hline$<0.05$ & 47.0 & $>3,200$ & 82.0 & 21.0 & 310.0 & 8.8 & 370 & 19 & 12,000 & 33.0 & 400.0 & 37 & 31.0 & $<1.5$ & 2,000 & 70.0 & 390 & 34.00 & 150 & 230.0 \\
\hline$<0.05$ & $<4.6$ & 1,400 & 10.0 & 1.2 & 19.0 & $<1.5$ & 55 & $<10$ & 1,600 & 5.3 & 22.0 & 10 & 7.7 & $<1.5$ & 2,300 & 9.9 & 63 & 3.70 & $<10$ & 46.0 \\
\hline$<0.05$ & $<4.6$ & 1,300 & 8.7 & 130.0 & 18.0 & $<1.5$ & 56 & $<10$ & 1,400 & 5.0 & 18.0 & $<10$ & 6.6 & $<1.5$ & 1,900 & 6.8 & 35 & 2.40 & $<10$ & 27.0 \\
\hline$<0.05$ & $<4.6$ & 550 & 1.8 & $<1.0$ & 3.5 & $<1.5$ & $<10$ & $<10$ & 590 & 3.5 & 2.3 & $<10$ & 6.2 & 3.2 & 3,200 & 2.8 & 44 & 2.80 & 250 & 9.4 \\
\hline$<0.05$ & $<4.6$ & 590 & 1.6 & 11.0 & 4.7 & $<1.5$ & $<10$ & $<10$ & 190 & 3.0 & 1.6 & $<10$ & 4.5 & $<1.5$ & 2,000 & 2.4 & 24 & 1.40 & $<10$ & 5.0 \\
\hline$<0.05$ & $<4.6$ & 520 & 1.2 & 6.8 & 4.6 & $<1.5$ & $<10$ & $<10$ & 170 & $<2.2$ & 1.5 & $<10$ & 4.9 & $<1.5$ & 2,400 & 2.1 & 18 & 1.10 & $<10$ & 5.5 \\
\hline$<0.05$ & $<4.6$ & 490 & $<1.0$ & $<1.0$ & 5.5 & $<1.5$ & $<10$ & $<10$ & 160 & $<2.2$ & $<1.5$ & $<10$ & 4.4 & $<1.5$ & 2,400 & 2.4 & 27 & 1.90 & $<10$ & 5.8 \\
\hline$<0.05$ & $<4.6$ & 570 & 1.7 & 4.6 & 3.3 & $<1.5$ & $<10$ & $<10$ & 160 & 4.3 & 1.7 & $<10$ & 6.0 & $<1.5$ & 2,400 & 2.7 & 31 & 1.80 & $<10$ & 8.3 \\
\hline$<0.05$ & $<4.6$ & 650 & 1.5 & $<1.0$ & 4.0 & $<1.5$ & 55 & $<10$ & 210 & $<2.2$ & $<1.5$ & $<10$ & 5.2 & $<1.5$ & 1,800 & 2.2 & 20 & 0.91 & $<10$ & 6.5 \\
\hline$<0.05$ & $<4.6$ & 980 & 3.6 & 1.8 & 5.5 & $<1.5$ & 74 & $<10$ & 490 & $<2.2$ & 2.6 & $<10$ & 6.5 & $<1.5$ & 3,200 & 3.6 & 41 & 2.60 & $<10$ & 8.2 \\
\hline$<0.05$ & $<4.6$ & 760 & $<1,0$ & 2.8 & 11.0 & $<1.5$ & $<10$ & $<10$ & 100 & 2.4 & $<1.5$ & $<10$ & 3.8 & $<1.5$ & 1,900 & 2.8 & 12 & 0.75 & $<10$ & 5.6 \\
\hline 0.10 & 23.0 & 560 & 2.6 & 230.0 & 59.0 & $<1.5$ & 63 & $<10$ & 310 & 39.0 & 260.0 & 10 & 8.5 & $<1.5$ & 4,000 & 590.0 & 110 & 8.90 & 750 & 68.0 \\
\hline 0.10 & $<4.6$ & 890 & 1.7 & 26.0 & 18.0 & $<1.5$ & $<10$ & $<10$ & 410 & 5.7 & 21.0 & $<10$ & 5.6 & $<1.5$ & 2,200 & 98.0 & 25 & 1.10 & $<10$ & 38.0 \\
\hline- & $<4.6$ & 520 & 1.6 & 260.0 & 26.0 & $<1.5$ & $<10$ & $<10$ & 190 & 7.7 & 32.0 & $<10$ & 6.5 & $<1.5$ & 2,900 & 130.0 & 40 & 2.10 & 270 & 49.0 \\
\hline$<0.05$ & 5.3 & 310 & 1.7 & 110.0 & 29.0 & $<1.5$ & $<10$ & $<10$ & 110 & 13.0 & 66.0 & $<10$ & 7.0 & $<1.5$ & 3,700 & 150.0 & so & 3.30 & 330 & 45.0 \\
\hline
\end{tabular}



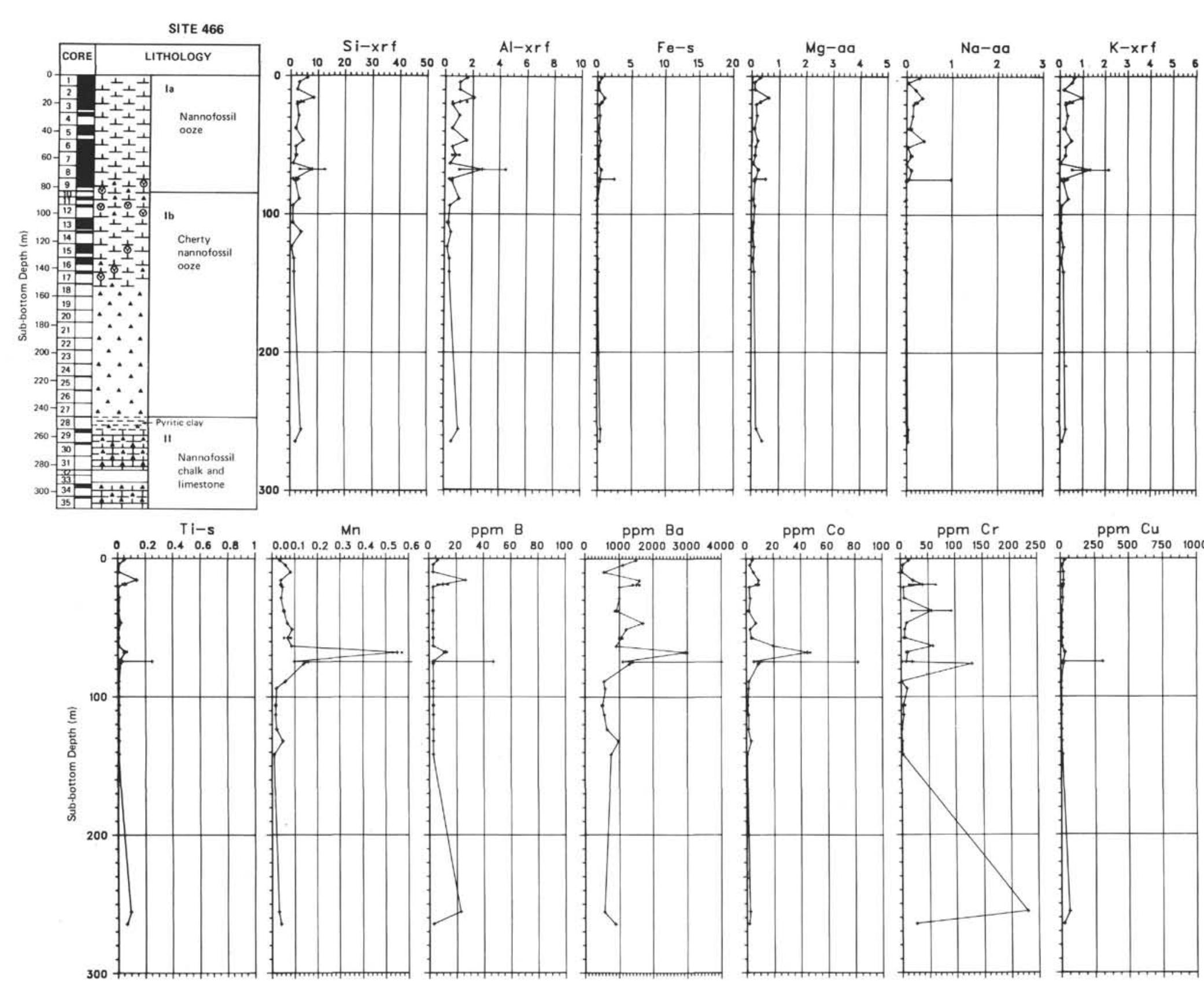

ppm Cu

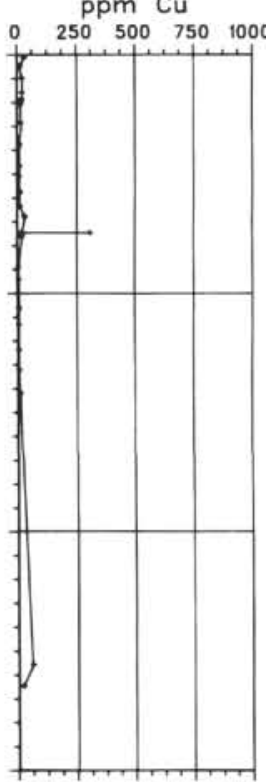


SITE 466
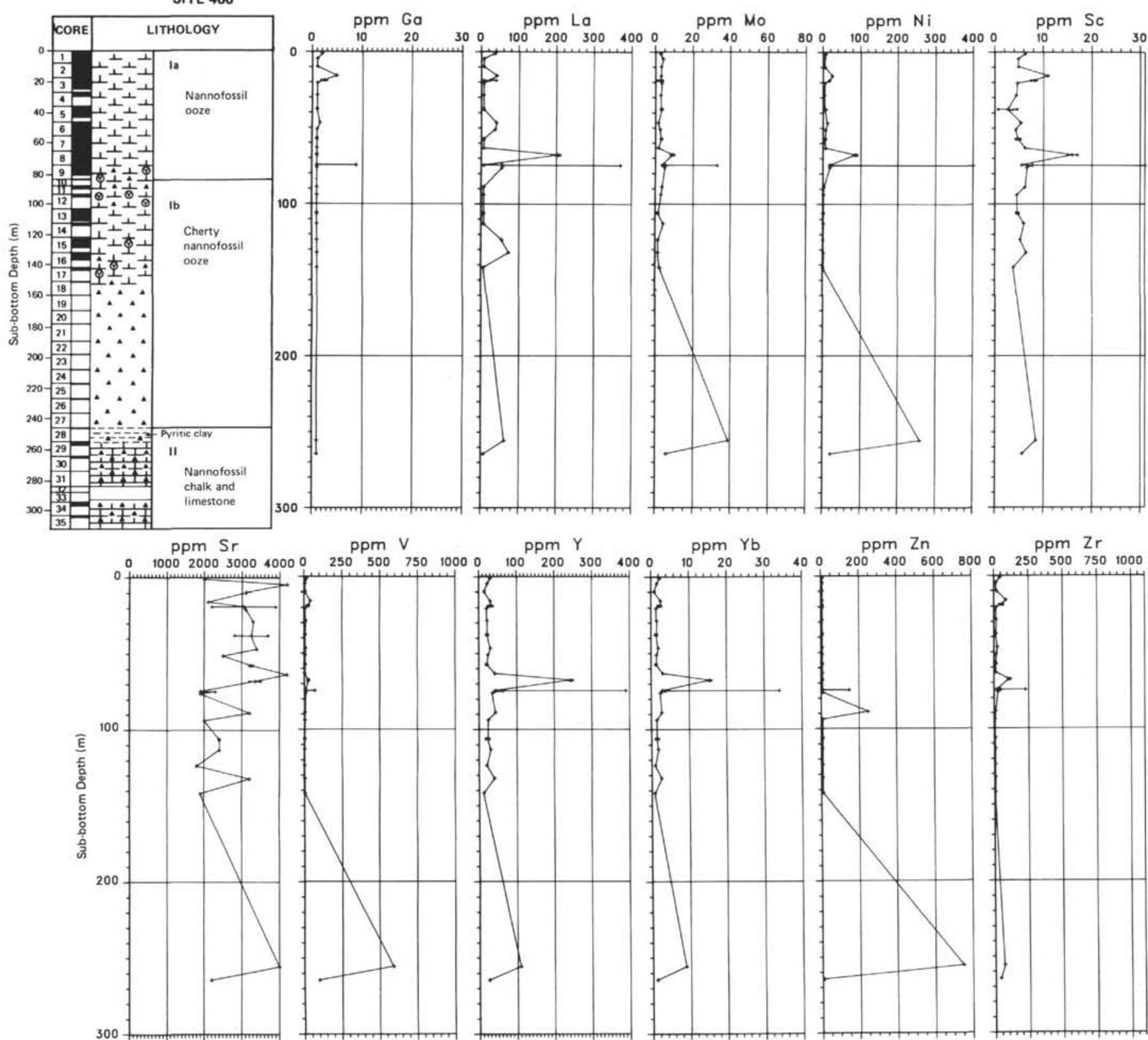

ppm Y

${ }_{10} \mathrm{Ppm}_{20} \mathrm{Yb}_{30}$

$\mathrm{ppm} \mathrm{Zn}$

$\mathrm{ppm} \mathrm{Zr}$
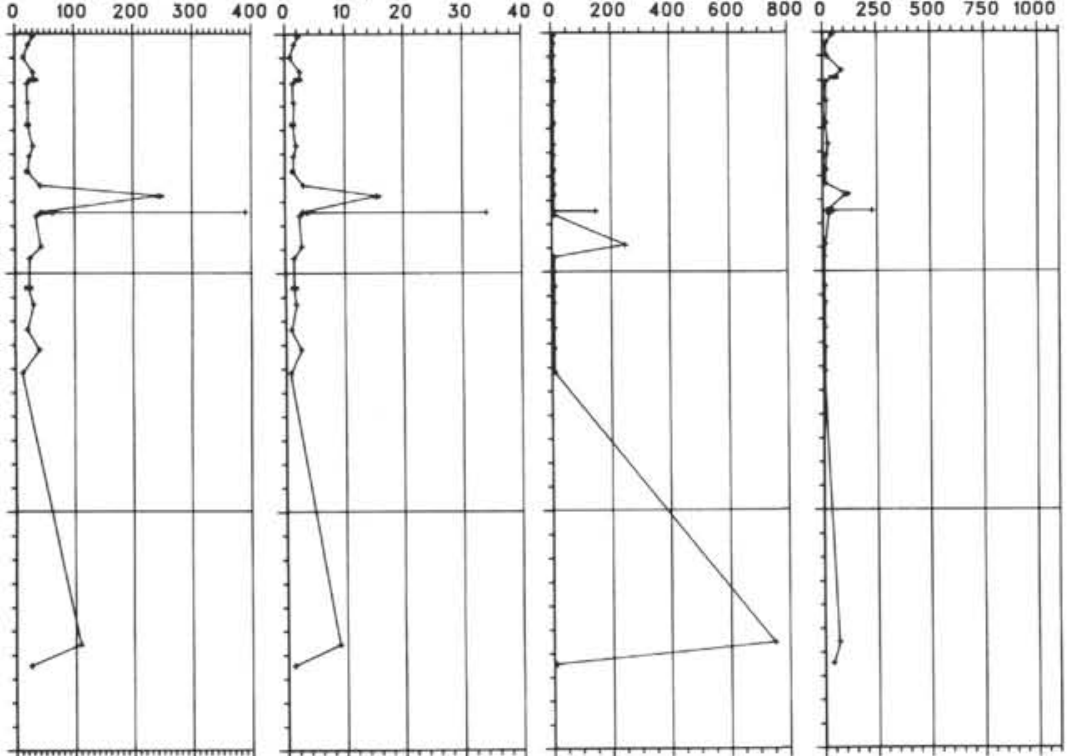

Figure 8. Lithologic summary and plots of element concentrations in samples from Hole 466. Element concentrations are in percent (unlabeled) or parts per million (labeled ppm) dry weight. Analyses were by X-ray fluorescence (xrf), semiquantitative optical emission spectroscopy (s), or atomic absorption spectrophotometry (aa). Duplicate analyses are indicated by two points connected by a horizontal bar at the same depth. The thickness of the black interval beside each core number in the column labeled "core" indicates the proportion of the cored interval that was recovered. 


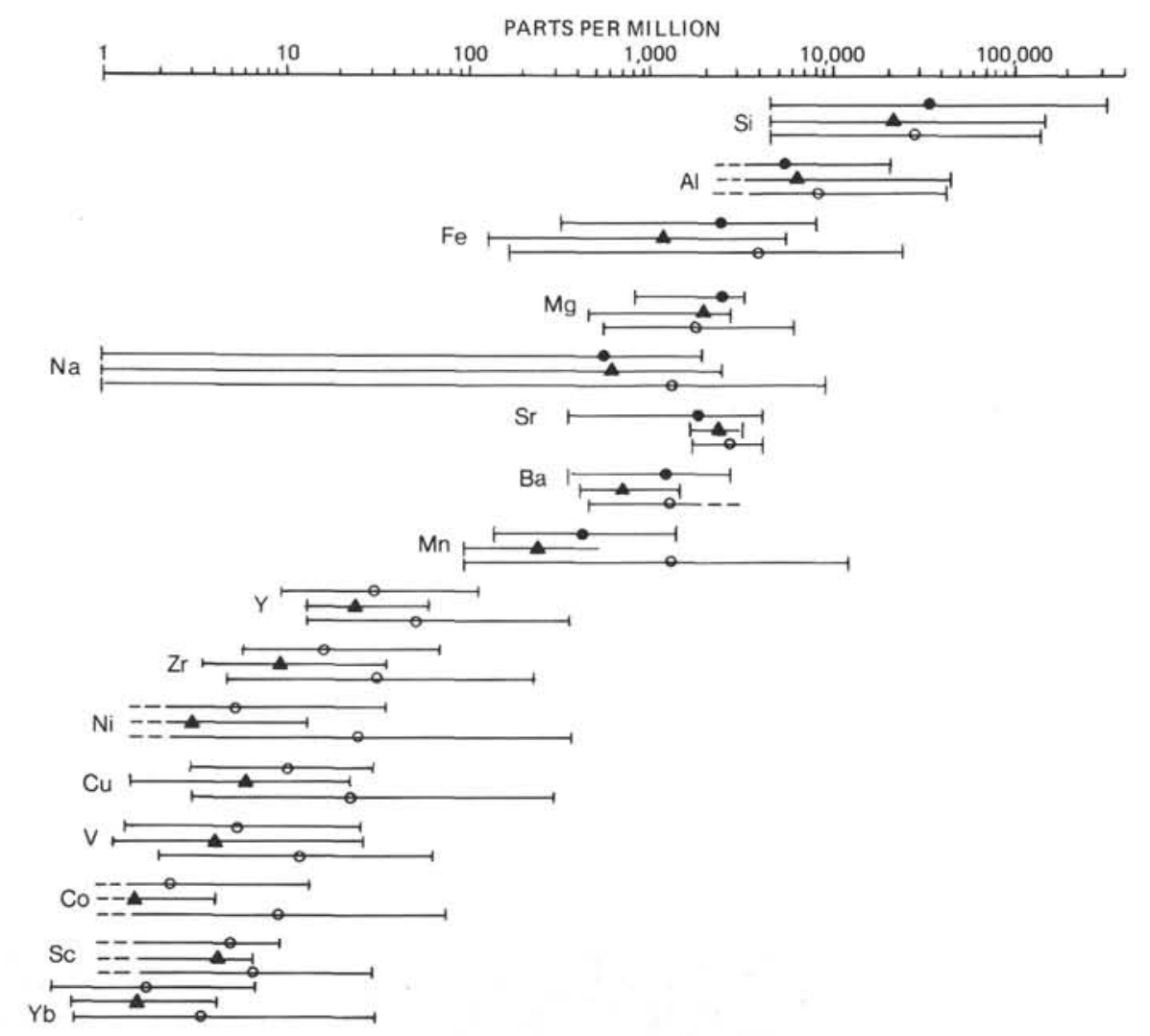

Figure 9. Comparison of element concentrations in 41 samples of nannofossil ooze and chalk from Lithologic Unit I, Hole 463 (dots); 25 samples of nannofossil ooze from Lithologic Unit I, Holes 465 and $465 \mathrm{~A}$ (triangles); and 29 samples of nannofossil ooze from Lithologic Unit I, Hole 466 (open circles). Dots, triangles and open circles represent the mean concentration for each element (Table 8). Bars indicate observed ranges of element concentrations (Table 8). A dash at the lower end of a bar indicates that the lowest concentration of the element was below the limit of detection.

Table 8. Summary statistics for total element concentrations in 41 samples of nannofossil ooze and chalk from Lithologic Unit 1, Hole 463; 25 samples of nannofossil ooze and chalk from Lithologic Unit I, Holes 465 and 465A; and 29 samples of nannofossil ooze from Lithologic Unit 1, Hole 466.

\begin{tabular}{|c|c|c|c|c|c|c|c|c|c|}
\hline \multirow[b]{2}{*}{ Element } & \multicolumn{3}{|c|}{ Hole 463} & \multicolumn{3}{|c|}{ Holes 465 and $465 \mathrm{~A}$} & \multicolumn{3}{|c|}{ Hole 466} \\
\hline & $\begin{array}{c}\text { Observed } \\
\text { Range }\end{array}$ & $\begin{array}{l}\text { Arithmetic } \\
\text { Mean }\end{array}$ & $\begin{array}{l}\text { Standard } \\
\text { Deviation }\end{array}$ & $\begin{array}{l}\text { Observed } \\
\text { Range }\end{array}$ & $\begin{array}{l}\text { Arithmetic } \\
\text { Mean }\end{array}$ & $\begin{array}{l}\text { Standard } \\
\text { Deviation }\end{array}$ & $\begin{array}{c}\text { Observed } \\
\text { Range }\end{array}$ & $\begin{array}{c}\text { Arithmetic } \\
\text { Mean }\end{array}$ & $\begin{array}{l}\text { Standard } \\
\text { Deviation }\end{array}$ \\
\hline Si $(\%)$ & $0.47-34$ & 3.4 & 5.5 & $0.47-14$ & 2.1 & 2.8 & $0.47-13$ & 2.9 & 2.5 \\
\hline Al & $<0.26-2.1$ & 0.55 & 0.34 & $<0.26-4.6$ & 0.64 & 0.92 & $<0.26-4.4$ & 0.87 & 0.84 \\
\hline $\mathrm{Fe}$ & $0.032-0.81$ & 0.26 & 0.18 & $0.013-0.58$ & 0.12 & 0.17 & $0.018-2.5$ & 0.40 & 0.47 \\
\hline $\mathrm{Mg}$ & $0.088-0.32$ & 0.16 & 0.054 & $0.047-0.29$ & 0.10 & 0.060 & $0.058-0.62$ & 0.18 & 0.13 \\
\hline $\mathrm{Na}$ & $0.0001-0.20$ & 0.057 & 0.051 & $0.0001-0.26$ & 0.062 & 0.079 & $0.0001-0.98$ & 0.13 & 0.20 \\
\hline K & $<0.024-0.36$ & - & - & $<0.024-1.1$ & - & - & $<0.024-2.2$ & 0.34 & 0.41 \\
\hline $\mathrm{Ti}$ & $<0.006-0.077$ & - & - & $<0.006-0.033$ & - & - & $<0.006-0.25$ & - & - \\
\hline $\mathrm{Ba}$ & $0.039-0.28$ & 0.12 & 0.049 & $0.043-0.16$ & 0.074 & 0.030 & $0.049->0.32$ & 0.125 & 0.080 \\
\hline $\mathrm{Mn}$ & $0.014-0.14$ & 0.045 & 0.029 & $0.0096-0.056$ & 0.026 & 0.016 & $0.010-1.2$ & 0.13 & 0.24 \\
\hline $\mathrm{Sr}$ & $0.038-0.42$ & 0.19 & 0.077 & $0.18-0.32$ & 0.23 & 0.046 & $0.18-0.42$ & 0.28 & 0.074 \\
\hline Co (ppm) & $1.0-15$ & 2.5 & 2.7 & $1.0-4.4$ & - & - & $1.0-82$ & 10 & 18 \\
\hline $\mathrm{Cu}$ & $3.1-31$ & 11 & 8.1 & $1.5-24$ & 6.7 & 6.2 & $3.3-310$ & 24 & 56 \\
\hline $\mathrm{La}$ & $10-90$ & - & - & $10-67$ & - & - & $10-370$ & - & - \\
\hline Mo & $<2.2-8.3$ & - & - & $<2.2-5.9$ & - & - & $<2.2-33$ & - & - \\
\hline $\mathrm{Ni}$ & $<1.5-38$ & 5.8 & 6.8 & $<1.5-13$ & - & - & $<1.5-400$ & 27 & 75 \\
\hline $\mathrm{Sc}$ & $<1.0-9.9$ & 5.2 & 2.0 & $<1.0-7.2$ & 4.7 & 1.4 & $<1.0-31$ & 7.1 & 5.6 \\
\hline $\mathrm{v}$ & $1.4-28$ & 6.0 & 5.8 & $1.2-29$ & 4.4 & 6.6 & $2.1-70$ & 12 & 15 \\
\hline Y & $10-110$ & 32 & 15 & $12-63$ & 25 & 9.8 & $12-390$ & 56 & 86 \\
\hline $\mathrm{Yb}$ & $0.57-7.6$ & 1.9 & 1.2 & $0.71-4.7$ & 1.7 & 0.80 & $0.75-34$ & 3.9 & 6.8 \\
\hline $\mathrm{Zr}$ & $6.1-74$ & 17 & 13 & $3.7-38$ & 9.8 & 8.3 & $5.0-230$ & 35 & 48 \\
\hline
\end{tabular}

